\title{
CÍCERO, DO ORADOR 2.216-290
}

\author{
Adriano Scatolin (tradução e notas adicionais)* \\ Charlene Miotti (introdução e notas)**
}

RESUMO: Tradução do excurso sobre o riso no diálogo Do orador (2.216-290), de Cícero, apresentado pelo personagem Gaio Júlio César Estrabão Vopisco.

PALAVRAS-CHAVE: Cícero; Do orador, humor oratório; Gaio Júlio César Estrabão Vopisco.

\section{CICERO, ON THE ORATOR 2.216-290}

ABSTRACT: This paper presents the translation of the excursus de risu from Cicero's dialogue On the orator (2.216-290), exposed by the character Gaius Julius Caesar Strabo Vopiscus.

KEYWORDS: Cicero; On the orator, oratorical humor; Gaius Julius Caesar Strabo Vopiscus.

\section{INTRODUÇão AO EXCURSO SOBRE O RISO (DE ORATORE 2.216-290)}

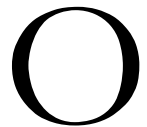
excurso sobre o riso (Cic. de Orat. 2.216-290), ora apresentado em tradução anotada, é a primeira obra supérstite da Antiguidade a propor uma teoria sobre o humor em contexto oratório. ${ }^{2}$

\footnotetext{
${ }^{1}$ Texto utilizado para a tradução: Kumaniecki, 1969. Todas as datas são a.C., salvo observação em contrário. Seguimos, para a notação dos textos antigos, as abreviações do Oxford Latin Dictionary. O tradutor agradece a Marlene Lessa Vergílio Borges pela cuidadosa revisão e a Tiago Augusto Nápoli pela "curta e grossa" solução sugerida para a piada de 2.245. Agradece ainda à Professora Charlene Miotti pela colaboração no trabalho, pela permissão de usar algumas soluções de seu Quintiliano na tradução e pela paciência com os prazos de entrega do tradutor.

${ }^{2}$ A segunda obra na Antiguidade latina a abordar essa temática será a Institutio oratoria (94-96 d.C.), de Quintiliano (6.3).
}

* Professor de Língua e Literatura Latina, Universidade de São Paulo.

adrscatolin@me.com (iD)

** Professora de Língua e Literatura Latina, Universidade Federal de Juiz de Fora. charlene.miotti@letras.uff.br 
Se em Platão e Aristóteles a questão do riso é abordada de modo periférico, circunscrita a outras matérias primordiais (por exemplo, a dimensão ética das manifestações artísticas no livro X da República, as afecções da alma no Filebo ${ }^{3}$ e a caracterização da comédia na Arte Poética $^{4}$ ), com Cícero e Quintiliano observa-se uma concentração exclusiva na matéria do risível, ocupando capítulos inteiros nas obras de ambos. Ainda que não esteja claro em que momento o riso passou a preencher as condições necessárias para se tornar objeto específico no ensino da arte retórica, com a ascensão do papel do orador nas sociedades antigas, também as instruções próprias para a construção de um discurso bem sucedido ganham espaço como assunto digno de relato e divulgação. Se, de fato, "a teoria do risível está mais bem tratada em Cícero que em qualquer outro autor grego", 5 não será demasiado supor que o contexto político da Roma republicana tenha fomentado o debate sobre o riso nos âmbitos ético e retórico, uma vez que os oradores assumiam o papel de condutores das deliberações diante do povo ou nas assembleias, ${ }^{6} \mathrm{e}$ muitos podem ter empregado o humor equivocadamente e em público, dada a reconhecida força persuasiva de um gracejo bem executado e a dificuldade em acertar a medida neste quesito.

Como se sabe, o De oratore é construído em diálogos, forma valorizada desde Platão por ser mais "leve"" tanto para a leitura como para a aprendizagem. Logo no segundo parágrafo (217, e em 256 e 288, menos explicitamente), o autor, pela voz de Gaio Júlio César Estrabão Vopisco ${ }^{8}$ - persona que conduz todo o excurso em diálogo com Marco Antônio, Lúcio Licínio Crasso e Públio Sulpício Rufo (em ordem de protagonismo) -, faz menção a livros gregos intitulados Do risivel, com os quais ele teria "alguma esperança de poder adquirir algum conhecimento". As fontes gregas de Cícero têm dado azo a muito debate: ${ }^{10}$ Demócrito é o único autor mencionado pelo nome (235) e paralelos verificáveis (ou seja, em obras supérstites, ainda que parcialmente) resumem-se à Poética ${ }^{11}$ e à Retórica ${ }^{12}$ de Aristóteles.

\footnotetext{
${ }^{3}$ Cf. $1448 \mathrm{c}-1450$ b, principalmente.

${ }^{4}$ Cf. 1449 a, principalmente.

${ }^{5}$ Romano, 2001, p. 163.

${ }^{6}$ Sobre as múltiplas funções do orador nos períodos republicano e imperial, cf. Cousin, 1975, p. xc.

${ }^{7}$ Sabe-se que os turnos de fala, reproduzidos em um texto, segmentam a discussão de forma natural e, muitas vezes, abrandam o rigor do assunto em pauta.

${ }^{8}$ Nascido por volta de 120 a.C., César Estrabão foi um advogado famoso (Brut. 207) cuja principal qualidade era o exercício do humor refinado em seus discursos.

${ }^{9}$ Marco Antônio, o orador, avô do mais famoso Marco Antônio, o triúnviro. "Antônio e Crasso tinham, tal como Cícero, ampla experiência nas causas e eram, segundo o autor quer nos fazer crer, os dois maiores oradores de sua época" (Scatolin, 2009, p. 16).

${ }^{10}$ Para um panorama mais detalhado, cf. Dominik; Hall, 2007, p. 212-15.

${ }^{11}$ Aristóteles, Poética, 1449a: “O ridículo é um defeito e uma deformação nem dolorosa nem destruidora, tal como, por exemplo, a máscara cómica é feia e deformada mas não exprime dor” (trad. de Ana Maria Valente); cf. de Orat. 2.236.

${ }^{12}$ Especialmente III, 4412a, cf. de Orat. 2.256.
} 
Em seu tratado, ${ }^{13}$ escrito quase 150 anos depois, Quintiliano faz referência às fontes gregas ${ }^{14}$

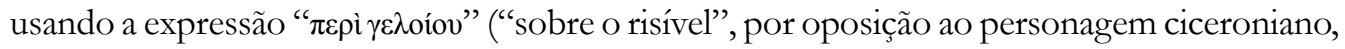
que, respeitando o decoro do diálogo, segundo o qual se evita o uso de terminologia grega, atém-se à expressão latina, de ridiculis), tornando mais verossímil a suposta influência da obra homônima (da qual nos restam apenas título e poucos fragmentos) de Teofrasto, ${ }^{15}$ sucessor de Aristóteles na condução da escola peripatética.

Em Cícero, encontramos acenos à questão do humor retórico no Orator (87-90) e no De officiis (1.103-104), mas é no De oratore (2.216-290) que vemos o tema desenvolvido de maneira rica e extensiva (ainda que não "sistemática"). Entre os contemporâneos de Cícero, somente o autor da Retórica a Herênio colaborou para o assunto, propondo uma curiosa definição (3.13.23: "jocosa é a fala que se aproveita de algo para suscitar um riso comedido e educado") ${ }^{16}$ e fornecendo um elenco de possibilidades às quais o orador pode recorrer quando o auditório estiver cansado de ouvi-lo (1.10.1ss.):

Se estiverem cansados de ouvir, partiremos de algo que possa provocar o riso: de um apólogo, uma fábula verossímil, uma imitação distorcida, uma inversão, uma ambiguidade, uma insinuação, uma zombaria, um disparate, um exagero, uma comparação, um trocadilho, algo além do esperado, uma semelhança, uma novidade, uma história, um verso, uma interpelação ou riso de aprovação de alguém; ou prometeremos que vamos falar algo diferente daquilo que preparamos, que não tomaremos da palavra do modo como outros costumam fazer - exporemos brevemente o que eles fazem e o que nós faremos. ${ }^{17}$

Vejamos, primeiramente, como Cícero conduz a questão no De oratore. Em resposta ao convite que lhe dirige Marco Antônio na manhã do segundo dia de diálogo, ${ }^{18}$ César toma a

\footnotetext{
${ }^{13}$ É clara e inegável a vinculação do tratado de Quintiliano àquele de Cícero, mas as duas obras diferem significativamente quanto à estruturação, aos propósitos, ao tom, ao valor literário e ao período em que vieram a público (55 a.C.-94 d.C.). Para maiores detalhes: Miotti, 2010, p. 106-29.

${ }^{14}$ Inst. 6.3.22: "o que é próprio da matéria sobre a qual agora debatemos é o ridículo, por isso toda essa discussão foi inscrita como $\pi \varepsilon p \grave{~} \gamma \varepsilon \lambda$ oíov pelos gregos" (tradução minha).

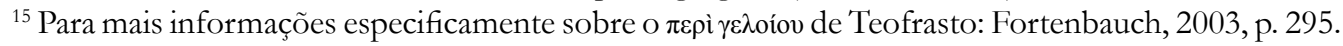
16 "Iocatio est oratio, quae ex aliqua re risum pudentem et liberalem potest conparare" (tradução de Ana Paula Celestino Faria e Adriana Seabra).

17 "Si defessi erint audiendo, ab aliqua re, quae risum mouere possit, ab apologo, fabula uerei simili, imitatione deprauata, inuersione, ambiguo, suspicione, inrisione, stultitia, exuperatione, collectione, litterarum mutatione, praeter expectationem, similitudine, nouitate, historia, uersu, ab alicuius interpellatione aut adrisione; si promiserimus aliter ac parati fuerimus, nos esse dicturos, nos non eodem modo, ut ceteri soleant, uerba facturos; quid alii soleant, quid nos facturi sumus, breuiter exponemus." (Tradução de Ana Paula Celestino Faria e Adriana Seabra).

${ }^{18}$ Como se sabe, Cícero encena o desenvolvimento do diálogo em dois dias consecutivos, durante as férias dos ludi Romani (ou seja, na primeira metade de setembro) do ano 91 a.C. (cf. De Orat. 2.24 ss.).
} 
palavra no parágrafo 217 e a conserva até o 227 para defender a tese de que o humor não pode "de modo algum [...] ser ensinado por meio de uma teoria", um método ou uma arte. Trata-se, no entanto, de uma típica capitatio beneuolentiae, já que César imediatamente demonstra vasto conhecimento sobre o assunto, introduzindo logo no parágrafo 218 a primeira dicotomia dos tipos de gracejos: a "jocosidade" (cauillatio) e a "mordacidade" (dicacitas).

Dos parágrafos 228 ao 234, o verdadeiro diálogo se estabelece, sendo esta a única cena na qual todos os personagens intervêm: Antônio, Sulpício (apenas em 231) e Crasso (somente em 232 e 234). Antônio explica as razões de ter confiado a César e não a Crasso (autor da maior parte dos ditos espirituosos compilados ali) a função de tratar deste aspecto da atividade oratória, no que é apoiado tanto por Sulpício como pelo próprio Crasso (que sublinha as limitações da teoria no exercício oratório, especialmente no tocante ao riso). Antônio mostra como César, apesar de negar a existência de uma "arte dos gracejos" (ars facetiarum), teria estabelecido ao menos um princípio: o de considerar as pessoas envolvidas, a situação e o momento, para evitar que a autoridade do discurso seja diminuída pelo uso do humor (um princípio que Crasso costuma respeitar, acrescenta). Daí, conclui que são mais bem aceitos os gracejos que proferimos quando fomos previamente atacados, do que aqueles nos quais tomamos a iniciativa (recomendação que se repete em Quintiliano, Inst. 6.3.13). ${ }^{19}$ Conforme já acenei, a partir do parágrafo 235 tem início o tratado do riso propriamente dito (estendendo-se até 289). A estrutura da investigação é fornecida imediatamente por César: "Cinco são as perguntas que se podem fazer acerca do riso: em primeiro lugar, qual é a sua natureza; em segundo, suas fontes; em terceiro, se cabe ou não ao orador querer provocar o riso; em quarto, em que medida; em quinto, quais são os tipos do risível."

As duas primeiras questões são resolvidas rapidamente. A explicação sobre a natureza do riso é delegada a Demócrito, ${ }^{20}$ uma vez reconhecida como algo irrelevante para o assunto proposto (235). A segunda pergunta é solucionada com base na formulação aristotélica de que o ridículo "é um defeito e uma deformação nem dolorosa nem destruidora" (Poética, 1449a), porque "ri-se unicamente, ou quase apenas, do que assinala e aponta alguma torpeza de maneira não torpe"21 (cf. ainda Inst. 6.3.8). O trunfo concreto de Cícero está mesmo nos desdobramentos das duas últimas indagações, admitida a afirmativa da terceira.

19 "Sem dúvida, a ocasião está tanto nas circunstâncias (e a sua força é tal que frequentemente, com a sua ajuda, não só os incultos, mas também os rudes conseguem dizer coisas engraçadas) quanto nas palavras que alguém tenha dito previamente, porque todas essas frases são de longe muito mais agradáveis [uenustiora] quando proferidas nas respostas do que nos ataques” (tradução minha).

${ }^{20}$ Demócrito (c. 460-352 a.C.) consagrou-se como "o filósofo que ri”, em oposição a Heráclito (c. 540-470 a.C.), “o filósofo que chora”, por conta da Carta de Hipócrates a Damagetus: "A história revela uma curiosa relação entre o riso, a sabedoria e a loucura. Conta a Carta que Hipócrates teria sido chamado pelos cidadãos de Abdera, cidade natal de Demócrito, porque o filósofo estaria gravemente enfermo, acometido de loucura - ria de qualquer coisa. Ao ouvi-lo e vê-lo, contudo, Hipócrates teria se convencido do contrário: Demócrito estaria mais sábio do que nunca." (Alberti, 2002, p. 74).

${ }^{21}$ De Orat. 2.236: "Locus autem et regio quasi ridiculi - nam id proxime quaeritur - turpitudine et deformitate quadam continetur; haec enim ridentur uel sola uel maxime, quae notant et designant turpitudinem aliquam non turpiter." 
A discussão acerca da medida, correspondente ao quarto ponto (237-239), estabelece como regra primordial a circunspecção em relação às afecções da "vítima": o ataque às pessoas que lhe são caras deve ser evitado (advertência mantida por Quintiliano: "é melhor perder a piada que perder o amigo", cf. Inst. 6.3.28). A segunda regra (discutida mais longamente) diz respeito aos assuntos dos quais se pode fazer troça sem perder autoridade (238): "é muito mais fácil brincar com o que não é digno de muito ódio nem de grande misericórdia”. Verena Alberti (2002, p. 58), em O riso e o risivel na história do pensamento, reforça que "à exceção dos facínoras que deveriam antes ser levados ao suplício e dos indivíduos cujo infortúnio torna simpáticos, o orador pode tornar risíveis todos os vícios da humanidade, assim como as deformidades e os defeitos corporais". Dessa forma, as instruções que visam limitar o emprego do risível no discurso coincidem com o que é legítimo para a arte retórica em geral: desde que observadas as pessoas, as circunstâncias e as ocasiões, tudo é permitido, se ajuda o orador a cativar o público e ganhar a causa.

O quarto ponto de César culmina com uma fronteira precisa sobre a qual insistirá (239): "preceitua-se não apenas que não se brinque de maneira insípida, mas também que, se surgir a oportunidade de um gracejo completamente absurdo, cumpre que o orador evite um e outro, a fim de que a brincadeira não incorra em bufonaria ou farsa". ${ }^{22}$ Cícero retoma aqui uma questão de ordem ética já estabelecida por Aristóteles ${ }^{23}$ quando aborda as paixões

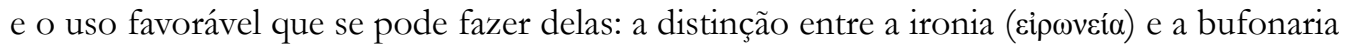

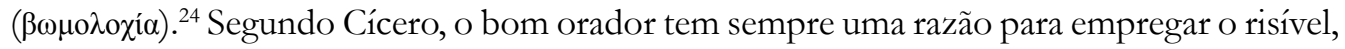
enquanto os bufões fazem troça o dia todo, disparando sátiras grosseiras contra qualquer um, sem considerar premissas éticas. É frequente que os temas dos discursos sejam delicados, quando não extremamente desagradáveis - isso, naturalmente, exige uma atenção especial do orador na escolha do teor das suas pilhérias, uma vez que o limite entre o sugerido e o explícito fica menos aparente. Cícero observa o cômico sob a perspectiva pragmática da realidade forense e, portanto, aloca em primeiro plano o seu aspecto técnico elocutivo.

O último ponto, referente aos gêneros do risível, ocupa todo o resto do tratado e constitui a parte mais extensa da discussão. César começa a responder à quinta questão com uma primeira distinção fundamental entre dois gêneros de gracejos: os que recebem tratamento segundo a matéria e os que recebem tratamento segundo a palavra (quorum alterum re tractatur, alterum dicto, 240). Atribui ao primeiro gênero a narração (narratio) e a imitação (imitatio), como procedimentos próprios dos gracejos contínuos ${ }^{25}$ (perpetuarum facetiarum),

\footnotetext{
22 "Itaque ea facillime luduntur, quae neque odio magno neque misericordia maxima digna sunt [...] in quo non modo illud praecipitur, ne quid insulse, sed etiam, quid perridicule possis, uitandum est oratori utrumque, ne aut scurrilis iocus sit aut mimicus."

${ }^{23}$ Cf. Retórica 3.18, $1419 \mathrm{~b}$ et seq.

${ }^{24}$ Naturalmente, as orientações de um e outro são ligeiramente diversas: a aristotélica diz respeito ao ator, a ciceroniana, ao orador.

${ }^{25}$ Em que se descrevem e se forjam os caracteres dos homens de tal forma que se perceba sua natureza por meio de alguma narração ou que se revelem, pela breve inserção de uma imitação, em algum defeito particularmente apto para a zombaria (243).
} 
indicando o excesso a evitar no comportamento dos mímicos (240-243). O risível que reside nas palavras (ridiculum in dicto), por outro lado, surge através da agudeza de um termo ou de um pensamento e seu uso abusivo configura a mordacidade própria dos bufões (scurrilis dicacitas), repetidamente exemplificada por César, a fim de que esteja claríssimo aquilo que o orador deve evitar neste campo (244-247). O esquema seria basicamente este:

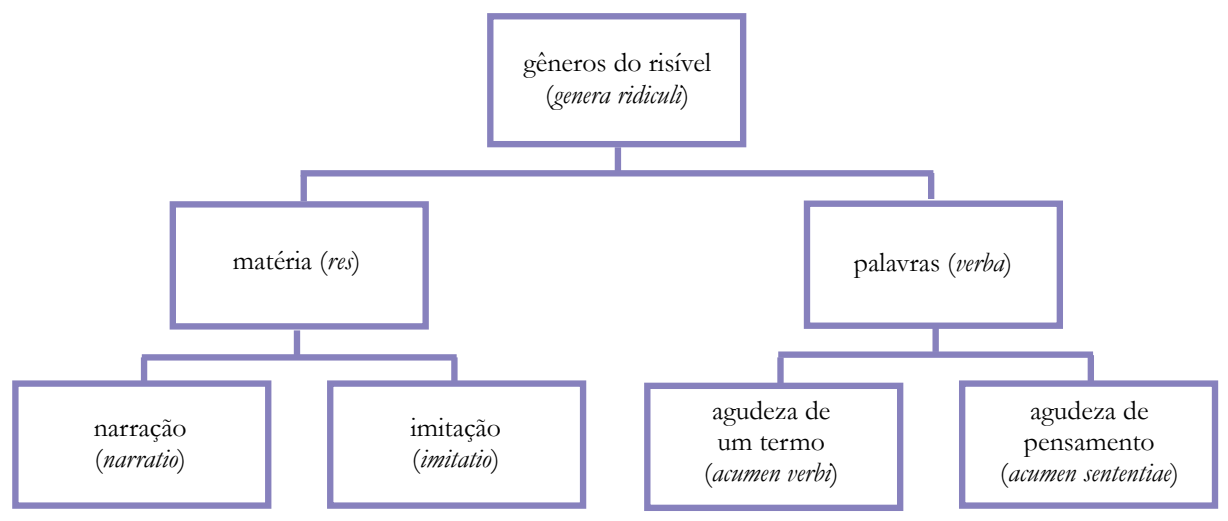

Em seguida, a exposição particularizada dos genera ridicula é anunciada, mas logo protelada para dar lugar à demonstração de que o ridículo e os pensamentos compartilham as mesmas fontes (248-250). Até onde se sabe, Cícero é o primeiro autor a fazer esta observação. $\mathrm{Nero}^{26}$ teria dito a respeito de um escravo ladrão (248): "é o único para quem não há nada fechado ou trancado na casa" - quando esse tipo de asserção costumava ser empregado em relação a pessoas que eram da maior confiança (episódio também comentado por Quintiliano em Inst. 6.3.50). Este caso é apresentado pelos dois autores como exemplo de que a mesma frase, empregada em situações diferentes, pode assumir perfeitamente tanto um caráter sério quanto jocoso: as circunstâncias da enunciação fundamentam o efeito humorístico.

Em 251, a advertência de que "nem tudo que é engraçado é gracioso" ("non esse omnia ridicula faceta", sendo este último termo eivado pelas noções de elegância e alegria) pretende reforçar os limites do tipo de humor que pode ser usado em contexto forense: ora, nem todas as brincadeiras que provocam riso são apropriadas para um uir bonus. ${ }^{27} \mathrm{O}$ próximo parágrafo (252) indica precisamente os quatro modos de risível que ultrapassam o domínio adequado ao orador (antes sacrificar uma anedota que sacrificar a dignidade, recomenda Quintiliano em Inst. 6.3.30): gestos afetados (mimica actio), imitação cômica (illiberalis imitatio, de que eventualmente o orador até pode fazer uso, mas rapidamente e com moderação),

\footnotetext{
${ }^{26}$ Este seria Gaio Cláudio Nero, que foi cônsul durante a segunda guerra púnica e venceu a batalha do Metauro em 207 a.C. Não confundir com o imperador que viveu em época posterior.

${ }^{27} \mathrm{O}$ homem de bem, perito no discurso, conforme a famosa definição do orador perfeito de Catão, o Velho: "orator est, Marce fili, uir bonus, dicendi peritus” (“O orador, meu filho Marcos, é um homem de bem, perito no dizer” frag. 14,80 ).
} 
careta (oris depranatio) e obscenidade (obscenitas). Idênticas, ainda que enumeradas de modo mais conciso, são as restrições da Institutio oratoria (6.3.29).

Retoma-se, então, a distinção dos gracejos in re e in uerbo, introduzindo o exame desses últimos, que compreendem oito gêneros. Enumero cada um deles, a fim de comentálos com mais vagar:

1. a ambiguidade (253-254), particularmente espirituosa se contraria a expectativa dos ouvintes (e que, para Quintiliano, é pouco eficiente, uma vez que precisa invocar referências conhecidas por todos, por exemplo, fatos atuais ou similaridades de som evidentes, cf. Inst. 6.3.48). No caso do exemplo de Vespa Terêncio, a ambiguidade reside no fato de que o braço quebrado, que impediu Tício de comparecer ao Campo de Marte, seria o da estátua;

2. a paronomásia (256), termo transliterado do grego $\pi \alpha \rho o v o \mu \alpha \sigma i ́ \alpha$, indicando a substituição de uma ou poucas letras para produzir um gracejo baseado no eco sobre a fala anterior. ${ }^{28}$ Muitos sobrenomes latinos, alguns estigmatizando aspectos físicos ou morais (tais como Seneca, o "velhote", Brutus, o "grosseiro", ou Bibulus, o "beberrão"), dão margem para a simples substituição de uma letra, alterações que engendram uma mudança de sentido cômica justificada pela quebra da expectativa do ouvinte: $M$. Fuluius Nobilior, o "notável", torna-se para Catão Mobilior, o "instável”. Conforme lembra George Minois, ${ }^{29}$ o próprio Cícero (de cicer, "grão-de-bico") não escapa às brincadeiras; mas, aos amigos que lhe aconselham mudar de nome, ele responde que tornará esse "grão-de-bico" tão célebre quanto Catão ("o prudente"), Catullus ("o cãozinho"30) ou Scaurus ("O de calcanhares inchados”);

\footnotetext{
${ }^{28}$ No Tractatus Coislinianus - um códice do século X d.C. que, apesar de seu estado fragmentário, apresenta claramente muitas definições semelhantes às de Aristóteles, e que alguns estudiosos, Richard Janko (1984, p. 1-4) entre eles, acreditam ser o agrupamento de trechos perdidos do Livro II da Poética

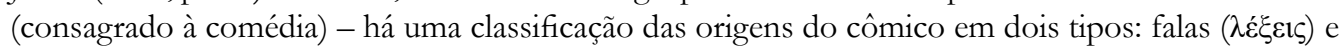

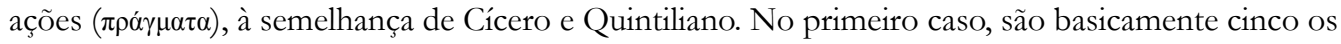
procedimentos enumerados (conforme Santoro, 2003, p. 277): a homonímia, a sinonímia, a prolixidade, a paronímia (por adição ou subtração - aqui se inserem os exemplos dos nomes modificados para criar um efeito cômico -, pelo diminutivo ou pelo trocadilho - com voz ou coisas de gênero semelhante) e o modo de falar. Quanto às ações, o códice elenca apenas nove itens: assimilação (para melhor ou para pior), o engano, o impossível, o possível e incoerente, a quebra de expectativa, a caracterização chula das personagens, o uso de danças vulgares, a escolha absurda (optar pelo pior quando o melhor está disponível) e o discurso desarticulado e incoerente.

${ }^{29}$ Minois, 2003, p. 85.

${ }^{30}$ Jean Granarolo (1982, p. 34) alerta, no entanto: "Não se pode autorizar conclusões seguras quanto ao cognomen Catullus. Pode-se, sem dúvida, fazê-lo derivar da palavra latina catulus... ou então de Cato, derivado ele próprio de catus [esperto, agudo]... Mas ninguém poderá esquecer que a raiz catu-, 'luta', 'guerra', é largamente representada na onomástica gaulesa...”.
} 
3. a citação de versos poéticos (257), em que o efeito cômico advém do deslocamento contextual (cf. Inst. 6.3.86);

4. a citação de provérbios (258; cf. Inst. 6.3.96-98);

5. a interpretação de uma frase no sentido literal e não segundo a intenção de quem a profere (259-260; cf. Inst. 6.3.85-87, quando Quintiliano aborda as estratégias da "simulação" e da "dissimulação");

6. o discurso mudado, immutata oratio (261), termo latino para a figura retórica da "alegoria";

7. o translado de uma única palavra, translatio uerbi (262), termo latino para a figura retórica da "metáfora"; e

8. a inversão do sentido das palavras, inuersio verborum (263), termo latino para a figura retórica da ironia. O chiste de Sérvio Galba está baseado nos termos latinos triclinium (um móvel que acomoda até três pessoas durante as refeições romanas, invocado por Libão) e cubiculum ("quarto", retorquido por Galba), sendo este último uma insinuação ao comportamento supostamente inapropriado de Libão.

Quanto aos gracejos baseados na matéria (in re) - os que provocam mais riso, segundo Cícero - podem-se identificar por volta de vinte tipos - todos os procedimentos que não extraem seu caráter cômico exclusivamente das palavras utilizadas, por exemplo: a imitação (dos gestos, da voz e da postura do adversário), a ingenuidade fingida (que será retomada insistentemente por Quintiliano, cf. Inst. 6.3.88, por exemplo) e a ironia: ${ }^{31}$

1. a narração (264), "algo bastante difícil, pois é preciso apresentar e colocar diante dos olhos elementos que não apenas pareçam verossímeis, [...] mas que também sejam um pouco torpes", como a narração de Crasso sobre Mêmio (240);

2. a história (caso de Sexto Tício e Antônio, que citam Cassandra e Ájax Oileu) e a comparação (265), como na resposta de Pisão a Escauro;

3. o retrato, quase sempre direcionado contra uma deformidade ou algum defeito corporal, como no caso de Hélvio Mância (266, cf. Inst. 6.3.38);

4. o exagero (267, cf. Inst. 6.3.67), ao qual Quintiliano também faz referência, mas usando o termo grego "hipérbole";

5. a alusão sagaz (significatio arguta, 268), quando se explica algo obscuro e misterioso por meio de um detalhe e, muitas vezes, de uma única palavra, como no caso Públio Cornélio e Caio Fabrício;

6. a ironia (dissimulatio) nas suas várias formas (269-272);

\footnotetext{
31 "Por Hércules, a essência de toda frase engraçada [salse dicendi] está nisto: dizê-la em um modo diverso do lógico e do verdadeiro" (Inst. 6.3.89). Ainda que Cícero e Quintiliano traduzam o termo

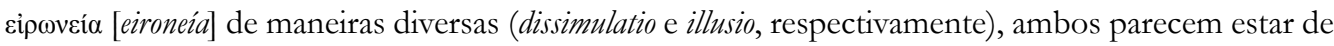
acordo com a definição: "a ironia demanda que as palavras sejam interpretadas ao contrário do que parecem significar” (cf. Inst. 6.2.15).
} 
7. o tangenciamento do absurdo (274-276), gênero "bastante trivial e [...] próprio dos mimos" (raros são os tipos de gracejos que, sendo apropriados aos "mimos e pantomimeiros" - cf. 240 - também o sejam aos oradores);

8. a interpretação de uma frase com sentido diferente daquele pretendido pelo enunciador (273), tipo de gracejo já mencionado em 259-260, entre os gracejos baseados nas palavras;

9. a zombaria que se devolve na mesma moeda (277), como na resposta de Décio a Quinto Opímio;

10. o subentendido ou a "suspeita velada" (278, cf. Inst. 6.3.88);

11. a piada irritadiça e mal-humorada ou a paciente e calma (279);

12. a repreensão da estupidez e as conjecturas inventadas, como no caso de Públio Rutílio, Escauro e Caio Cânio (280);

13. a incongruência (281; cf. Inst. 6.3.84);

14. a repreensão amigável de alguém (281), como se ele estivesse cometendo um erro, como na censura de Grânio a Álbio;

15. o conselho (282), em que mais um diálogo de Grânio constitui exemplo;

16. a frase adequada aos predicados do adversário (283), gracejo fino que a frase de Caio Mêmio a Escauro ilustra;

17. aquele que contraria as expectativas (284-285), como na frase de Ápio, o Velho, pronunciada no senado a respeito do gado errante de Luculo;

18. a aplicação ao adversário daquilo que ele próprio usou contra nós (286), tipo de gracejo do qual Caio Lélio se faz porta-voz;

19. a brincadeira em tom sentencioso (286), como a réplica de Marco Cíncio a Caio Cento;

20. a expressão de um desejo irrealizável (287), como o que fez Marco Lépido ao se deitar na grama enquanto os demais se exercitavam no Campo de Marte;

21. a enunciação impassível de uma resposta indesejada $\left(287^{32}\right)$, como fez o censor Lépido quando expulsou Marco Antístio Pirgense da ordem equestre.

Enfim, César resume sua exposição (que é, sobretudo, uma compilação de exemplos) e a conclui, retomando uma imagem já utilizada por Antônio no parágrafo 234: César convida o amigo a deixar a "hospedaria" (denersorium) de sua fala e retomar seu caminho, pois ele esperava encontrar um pouco de repouso durante o discurso (como um viajante

\footnotetext{
${ }^{32}$ Quintiliano narra episódio semelhante em Inst. 6.3.64: "Os tipos de chistes que derivam de opostos são mais de um. Com efeito, usando esse método, Augusto, que deveria demitir com ignomínia um oficial que repetidamente intercalava às súplicas a seguinte frase: 'O que vou dizer a meu pai?', respondeu: 'Diga-lhe que eu não lhe agradei'."
} 
que busca pousada durante uma viagem) e o assunto revelou-se, por fim, menos tranquilo do que se imaginava. ${ }^{33}$

De fato, o assunto que Cícero se propõe a tratar está longe de um desfecho pacífico. $\mathrm{O}$ excurso sobre o riso se coloca no âmbito de uma discussão absolutamente relevante e delicada até os nossos dias: os limites do humor nas variadas circunstâncias sociais. Sírio Possenti, ${ }^{34}$ um dos mais conhecidos e respeitados linguistas brasileiros da atualidade, dedicado à pesquisa sobre humor na área da análise do discurso, referiu-se ao tratado de Quintiliano, no qual muitas das ideias ciceronianas se confirmam, ${ }^{35}$ da seguinte maneira: "as piadas que ele cita funcionam perfeitamente hoje (eu morri de rir lendo a tradução), para surpresa, imagino, dos que defendem que o humor é cultural. Se fosse, o dos romanos deveria ser bem diferente do nosso, e não acharíamos a menor graça em suas tiradas. Mas não é o que acontece."

A tradução de Adriano Scatolin alia o rigor científico ao didatismo dos bons manuais, conduzindo o leitor de maneira prazerosa pela vasta casuística ciceroniana. Desejo ao leitor, leigo ou acadêmico, que se permita dar boas risadas ao ler as piadas que Cícero reporta em seu texto, demonstrando esforço inédito para examiná-las e classificá-las. Se pensarmos em profissões modernas que assimilaram traços da oratória clássica (me ocorrem políticos, advogados, professores, apresentadores e todos aqueles que tomam a palavra em público como parte de seu ofício), não será difícil perceber que Cícero foi um visionário cujas lições perduram não apenas porque são atemporais, mas também por conta de semelhanças desconcertantes que, dois milênios mais tarde, ainda guardamos com a antiga Roma.

\section{TraduÇão}

Por outro lado, ${ }^{36}$ são agradáveis e muitas vezes bastante úteis a brincadeira e os gracejos; ${ }^{37}$ estes, ainda que tudo mais possa ser ensinado pela arte, são certamente próprios da natureza, não carecendo de arte alguma. Neles, você, César, ${ }^{38}$ na minha opinião, supera

\footnotetext{
${ }^{33} \mathrm{O}$ reconhecimento sobre a dificuldade do tema inaugura o tratado de Quintiliano (Inst. 6.3.1-3).

${ }^{34}$ Possenti, 2014, p. 9.

${ }^{35}$ Odgers (1933, p. 186-187) nos lembra que: "para Quintiliano, o nome de Cícero é verdadeiramente sinônimo da eloquência propriamente dita. Quase três quintos das suas citações de literatura latina são de Cícero. A maior parte delas são referências ao Orator, ao De oratore e outras obras retóricas; muitas são alusões aos discursos ou citações deles, pois Quintiliano acredita que não poderá encontrar melhores ilustrações do que aquelas fornecidas por Cícero".

${ }^{36} \mathrm{O}$ excurso sobre o riso começa no meio do parágrafo 216, quando Marco Antônio discute as emoções por meio das quais se pode comover o juiz.

${ }^{37}$ Como observam com precisão LPR, p. 212 ad 'utilis': “"agradável' para o ouvinte e, por isso mesmo, 'útil' para o orador".

${ }^{38}$ Nascido por volta de 131, Gaio Júlio César Estrabão Vopisco, o protagonista do excurso sobre o riso, foi um orador famoso da geração anterior à de Cícero, cuja principal qualidade era o exercício do humor refinado em seus discursos (cf. Cic. de Orat. 2.98; 3.30; Brut. 177; 207; Tusc. 5.55; Off.
} 
em muito os outros: um motivo a mais para que possa ser minha testemunha de que não existe nenhuma arte do humor ou, se houver, é sobretudo você quem nos há de ensiná-la.

217. - Na verdade - respondeu ele -, creio que um homem que não seja grosseiro é capaz de discutir a respeito de qualquer assunto com mais graça do que sobre os próprios gracejos. Assim, por exemplo, quando vi alguns livros gregos ${ }^{39}$ intitulados Do risivel, ${ }^{40}$ cheguei a ter alguma esperança de poder adquirir algum conhecimento com eles. Encontrei muitas coisas engraçadas e espirituosas entre os gregos: de fato, os sicilianos, ${ }^{41}$ bem como os rodienses, os bizantinos e, mais que todos, os áticos, sobressaem-se nesse campo. Porém, aqueles que tentaram ensinar um método e uma arte desse tema revelaram-se de tal modo insípidos, que não se ri senão de sua própria insipidez. 218. Por isso, ao menos para mim, não parece que isso possa de modo algum ser ensinado por meio de uma teoria. $\mathrm{Na}$ verdade, sendo dois os tipos de gracejos, um deles espalhado de maneira uniforme por toda a fala, o outro, muito incisivo e rápido, os antigos denominaram o primeiro "jocosidade", o segundo, "mordacidade". ${ }^{42}$ Que nome trivial têm os dois! Não é para menos, já que é absolutamente trivial provocar o riso... 219. No entanto, Antônio, ${ }^{43}$ como você diz, ${ }^{44}$ notei ${ }^{45}$ que não raro são de muito proveito, nas causas, o humor e os gracejos. Ora, tal como não se carece de arte no primeiro tipo, o da espirituosidade contínua ${ }^{46}$ - pois a natureza forja e cria os homens

1.108; 133; referências em LPN, 1985, p. 205-6; LPR, 1989, p. 212 ad 'Caesar’; May; Wisse, 2001, p. 15; Fantham, 2004, p. 22-3; p. 139, com n. 22).

${ }^{39}$ Sobre as fontes gregas de Cícero, cf. Rabbie, 2007, p. 212-5.

${ }^{40}$ De ridiculis traduz o grego $\pi \varepsilon \rho \grave{~} \gamma \varepsilon \lambda$ oíov. Quintiliano, em 6.3.22, ao definir a matéria do capítulo dedicado ao humor oratório, adota o singular, ridiculum: "O que é próprio da matéria sobre a qual

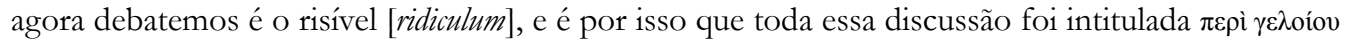
pelos gregos."

${ }^{41}$ Cf. parágrafos 278 e 280, com exemplos de gracejos envolvendo sicilianos. Os sicilianos são elencados entre os gregos porque, na Antiguidade, houve colonização helênica no sul da Itália e a região ficou conhecida por "Magna Grécia".

${ }^{42}$ Segundo Grant, 1924, p. 110, há indicações de que a primeira divisão dos genera facetiarum que Cícero faz no De oratore (precisamente, entre cauillatio e dicacitas), ou entre facetus e dicax (se tomarmos os adjetivos correspondentes), não está dissociada da divisão in re e in uerbo que se fará no parágrafo 248. Considere-se também que Cícero frequentemente refere-se à cauillatio (os membros da dicotomia são, em Orator 87, facetiae e dicacitas) no De oratore como haec perpetua (221), perpetua festiuitas (219) etc. No parágrafo 243, onde se resumem os dois exemplos de gêneros de gracejos in re, ele diz: "ergo haec duo genera sunt eius ridiculi, quod in re positum est, quae sunt propria perpetuarum facetiarum" ("Esses são, portanto, os dois gêneros do risível que residem na matéria. Eles são próprios dos gracejos contínuos...”). Aqui, faz-se uma conexão explícita entre facetum e o ridiculum in re.

${ }^{43}$ Marco Antônio, o orador, foi avô do mais famoso Marco Antônio, o triúnviro (Conte, 2011, p. 162).

${ }^{44} \mathrm{Em} 2.216$, acima.

${ }^{45} \mathrm{Tal}$ como acontece no caso dos protagonistas Crasso e Antônio, também César Estrabão pauta sua fala em sua experiência nas causas.

46 "Espirituosidade contínua" glosa e explica “jocosidade”. 
como imitadores e narradores engraçados com a ajuda do rosto, da voz e do próprio modo de falar ${ }^{47}-$, da mesma forma, neste segundo tipo, o da mordacidade, que lugar tem a arte, ${ }^{48}$ quando é preciso desferir e acertar o dito sarcástico antes que pareça ter havido tempo para se pensar? 220. Que ajuda, com efeito, este meu irmão aqui presente podia receber da arte quando, questionado por Felipe por que ladrava, respondeu que estava vendo um ladrão?49 E Crasso ${ }^{50} \mathrm{em}$ todo o seu discurso, fosse contra Cévola, ${ }^{51}$ perante os centúnviros, ${ }^{52}$ ou contra o acusador Bruto, ${ }^{53}$ quando defendia Planco ${ }^{54} \mathrm{Na}$ realidade, o que atribui a mim, Antônio, deve, por consenso geral, ser concedido a Crasso. De fato, não se encontrará quase ninguém além dele que se sobressaia nos dois tipos de humor, tanto aquele, que se espalha ao longo da fala, como este, que se encontra num dito ágil. 221. De fato, toda aquela defesa de Cúrio ${ }^{55}$

${ }^{47}$ Cf. Quint. Inst. 6.3.11-12: “Como não ousaria dizer que o humor, seja qual for a sua essência, está completamente privado de técnica, já que existem determinadas regras e se conhecem os preceitos gregos e latinos pertinentes a ele, afirmo, assim, plenamente convencido, que o humor se baseia particularmente na disposição natural e na ocasião. Contudo, o instinto não serve só para determinar quem é mais habilidoso ou mais agudo em provocá-lo (pois isso certamente pode ser desenvolvido através da teoria); mas consiste em uma harmonia tal, na apresentação e na aparência, que, se as mesmas frases fossem proferidas por outro, pareceriam menos urbanas."

${ }^{48}$ Diverso o posicionamento de Cícero em Orat. 90: “[sc. Demóstenes] não era tão mordaz quanto gracioso, e o primeiro é próprio de uma natureza mais penetrante, o segundo, de maior arte”.

${ }^{49}$ Inst. 6.3.81: "Algo parecido é não negar o que se apresenta, mesmo quando isso for obviamente falso, e daí encontrar argumento para responder bem, como fez Cátulo a Filipe, que lhe interrogava 'por que ladra?': 'estou vendo um ladrão', disse.” A pergunta de Filipe (especificamente, com a escolha do verbo latrare) encerra também um trocadilho com a palavra catulus (que, além do nome próprio, "Cátulo", pode significar "cãozinho"), detalhe que o texto ciceroniano apaga: trata-se de um gracejo baseado em palavras que é difícil de reproduzir em outra língua. A tradução para o português (tentando compensar a perda inicial) evidencia o efeito desejado por Cátulo (o jogo "ladrar - ladrão"), enquanto o original, tanto em Cícero como em Quintiliano, é mais sutil (fur é a palavra mais corrente para "ladrão", mas existe a forma latro, invocada já na pergunta de Filipe).

${ }^{50}$ Lúcio Licínio Crasso (c. 140-91), protagonista do diálogo, toma a palavra no excurso sobre o riso somente nos parágrafos 232 e 234. "Antônio e Crasso tinham, tal como Cícero, ampla experiência nas causas e eram, segundo o autor quer nos fazer crer, os dois maiores oradores de sua época" (Scatolin, 2009, p. 16).

${ }^{51}$ Quinto Múcio Cévola (c. 140-82), personagem que deixara a discussão e a propriedade de Crasso no dia anterior, na ficção do diálogo.

${ }^{52} \mathrm{O}$ tribunal dos centúnviros existiu na última fase da República e nos primeiros séculos do Império romano. Era formado por aproximadamente cem magistrados (105 membros no fim da República e 180 no período imperial) que julgavam questões do Estado, de propriedade e de direitos de sucessão (Nóbrega, 1977, p. 400).

${ }^{53}$ Marco Júnio Bruto, o Velho, pai do famoso Marco Júnio Bruto, um dos assassinos do general Júlio César.

${ }^{54}$ Gaio Munácio Planco ou Gneu Plâncio (a grafia do nome varia nos manuscritos) é um personagem sobre o qual pouco se sabe (cf. 2.223-226, Inst. 6.3.43-44 e Iso, 2002, p. 302).

${ }^{55}$ Mânio Cúrio, cuja causa é referida em de Orat. 1.180. 
contra Cévola foi rica em uma espécie de bom humor e de brincadeira do começo ao fim. Não apresentou aqueles ditos breves, pois poupava a dignidade do adversário, com o que preservava a sua própria. Isso é dificílimo para pessoas espirituosas e mordazes: respeitar as pessoas e as circunstâncias e guardar para si o que lhes ocorre, quando poderia ser dito com toda a malícia. Algumas pessoas engraçadas interpretam esse próprio fato de maneira nada insípida. 222. De fato, dizem que $\hat{E}{ }^{2}{ }^{56}$ afirma que é mais fácil um sábio prender o fogo na boca em chamas do que guardar bons ditos para si. É evidente que são bons ditos por serem maliciosos, pois são chamados de ditos já por denominação própria. Mas tal como Crasso calou-os na causa contra Cévola, conduzindo o pleito e a discussão com aquele segundo tipo de humor, em que não havia nenhum aguilhão de insulto, da mesma maneira, na causa contra Bruto, a quem odiava e julgava merecedor de insultos, combateu fazendo uso de ambos os tipos de humor. 223. Como se alongou sobre os banhos que Bruto acabara de vender, como se alongou sobre a perda de seu patrimônio ${ }^{57}$ Sem contar que respondeu com aquela breve observação, quando Bruto disse estar suando sem motivo: "Não é para menos, você acaba de sair dos banhos!" Houve inúmeras observações desse tipo, mas não foram menos divertidas aquelas espalhadas ao longo do discurso. De fato, como Bruto apresentara dois leitores ${ }^{58}$ e dera, para que lessem, a um, o discurso de Crasso Da colônia narbonense, a outro, o Da lei Servília, confrontando tópicos políticos contraditórios, ${ }^{59}$ nosso querido Crasso aqui, de maneira extremamente espirituosa, deu a três leitores os três opúsculos Do direito civil, do pai de Bruto. ${ }^{60}$ 224. Do primeiro livro: Calhou que estivéssemos na propriedade de Priverno. "Bruto, seu pai é testemunha de que lhe deixou uma propriedade em Priverno". Em seguida, do segundo livro: Estávamos, eu e meu filho Marco, na propriedade de Alba. "É evidente que esse homem, dos mais sábios desta cidade, conhecia esse poço sem fundo:

\footnotetext{
${ }^{56}$ Quinto Ênio (240-169), autor dos Annales (poema épico sobre a história de Roma, cf. Brut. 73). A passagem citada corresponde ao fragmento $412 \mathrm{~V}$ de Scaenica (Vahlen, 1928).

${ }^{57} \mathrm{~A}$ anedota é contada por Cícero também em Cluent. 51. Quintiliano a narra de modo mais resumido em Inst. 6.3.43-44: "Já que Bruto, na acusação de Gaio Planco, estava mostrando, com a ajuda de dois leitores, que Lúcio Crasso (defensor de Planco), no discurso Da colônia narbonense, havia dito o contrário daquilo que aconselhou no caso da Lei Servília, Crasso providenciou também três leitores e lhes deu os diálogos do pai de Bruto, para que o lessem. Como expusesse as conversas tidas uma em Albano, outra em Priverno e a terceira em Tíbur, Crasso perguntou onde estariam essas propriedades no momento. Bruto, porém, havia vendido todas elas e, naquele tempo, alienar as posses paternas era considerado ainda mais vil."

${ }^{58}$ Possivelmente seus escravos ou libertos, usados na ocasião para ler em voz alta passagens dos discursos anteriores de Crasso.

${ }^{59}$ Cícero alude ao comportamento ambíguo de Crasso que, em 118, criticara os senadores na ocasião em que se discutia o projeto de fundar uma colônia em Narbo, mas doze anos depois, em 106, os elogiou durante o debate da lei proposta por Servílio Cipião, que encarregava ao senado as cortes de justiça. ${ }^{60}$ Enquanto Cícero argumenta, em Off. 2.50, que Bruto merecia o epíteto de delator por tê-lo difamado, menciona que ele era filho de um célebre jurisconsulto ("qui iuris ciuilis in primis peritus fuit”). Segundo Pompônio, o pai de Bruto teria escrito sete livros sobre direito civil. Aqui, entretanto, Cícero afirma que a obra era dividida em apenas três livros.
} 
temia que considerassem que, por nada ter, nada lhe fora legado". Então, do terceiro livro, com o qual encerra a obra - esse é o número, segundo ouvi de Cévola, dos livros autênticos de Bruto: Encontrávamo-nos por acaso, eu e meu filho Marco, na propriedade de Tíbur. "Onde estão essas propriedades, Bruto, que seu pai lhe legou, consignadas em apontamentos públicos? É que se você não fosse já adulto - continuou -, teria composto um quarto livro e teria deixado escrito que falara com seu filho também nos banhos". 225. Quem há, então, que não reconheça que Bruto foi refutado igualmente por esse humor e esses gracejos e pelos efeitos trágicos a que recorreu quando, por acaso, ao mesmo tempo em que decorria o julgamento, a velha Júnia era levada em cortejo fúnebre? ${ }^{61}$ Pelos deuses imortais, que força era aquela, quão grande! Quão inesperada! Quão repentina! Com os olhos inquisitivos, com o gesto todo ameaçador, com extrema gravidade e rapidez nas palavras, disse: "Bruto, por que está aí sentado? O que deseja que aquela senhora conte a seu pai? E a todos aqueles cujos retratos você vê sendo levados? E a seus ancestrais? E a Lúcio Bruto, ${ }^{62}$ que libertou este povo da tirania dos reis? O que deve ela dizer que você está fazendo? Que aspira a que objetivo, a que glória, a que virtude? Ao aumento de seu patrimônio? Mas isso não convém à nobreza. Ainda que conviesse, porém, já não resta nada, os prazeres tudo dissiparam. 226. Ao direito civil? Mas é um legado paterno. Ora, ela contará que, ao vender sua casa, você não reservou para si, dos bens móveis, nem mesmo o sólio de seu pai. Acaso à arte militar? Mas você nunca viu um acampamento! À eloquência? Você não a tem, e o pouco que lhe resta de voz ou de língua, já o dedicou inteiramente a esse tão vergonhoso lucro com a calúnia! Você ousa contemplar a luz? Ousa olhar para eles? Ousa aparecer no fórum, na cidade, à vista dos cidadãos? Não treme perante essa morta, perante os próprios retratos? Você não deixou nenhum espaço para imitá-los ou mesmo para colocá-los em seu átrio.” 227. Mas essas foram palavras trágicas e divinas. Quanto às engraçadas e espirituosas, vocês podem se lembrar de incontáveis delas, mesmo numa única assembleia popular. De fato, jamais houve impetuosidade maior, nem discurso mais grave perante o povo, do que o proferido recentemente por este homem contra seu colega de censura, ${ }^{63}$ nem mais salpicado de humor e espirituosidade. É por isso que concordo com você, Antônio, nesses dois pontos: muitas vezes os gracejos trazem grande proveito ao discurso, ao mesmo tempo em que não podem, de forma alguma, ser ensinados por meio de uma arte. Admira-me o fato de que você tenha atribuído tanto a nós no que concerne ao humor, e não tenha concedido a palma da vitória a Crasso também nesse aspecto, tal como nos demais.

228. Respondeu então Antônio:

- Eu o faria, se por vezes não tivesse um pouco de inveja de Crasso nesse aspecto. De fato, ser bastante engraçado e arguto não é, por si só, muito invejável. Porém, sendo ele o mais

\footnotetext{
${ }^{61}$ Para Iso (2002, p. 304), esta Júnia seria da mesma gens que Bruto, mas possivelmente não relacionada a ele diretamente. Para Norcio (1970, p. 365), Júnia era “avó de Júnio” Bruto.

${ }^{62}$ Lúcio Júnio Bruto, lendário fundador da República romana (cf. Tac. Ann. 11.22-24).

${ }^{63}$ Em 92, Crasso exercera a censura juntamente com Cneu Domício Enobarbo.
} 
encantador e o mais urbano de todos, ao mesmo tempo ser e parecer o mais austero e o mais sério de todos, algo que toca unicamente a ele, parecia-me quase insuportável.

229. Como o próprio Crasso risse nesse momento, continuou Antônio:

- E, no entanto, Júlio, ao afirmar que não existe uma arte dos gracejos, você revelou algo que parecia digno de preceituação: disse que cumpria levar em conta as pessoas, o caso, a circunstância, a fim de que a brincadeira não diminuísse em nada a gravidade, algo que sobretudo Crasso costuma observar. Mas esse preceito concerne aos gracejos a serem omitidos, quando são absolutamente inoportunos. Quanto a nós, investigamos de que maneira empregá-los quando houver necessidade, como, por exemplo, contra um adversário e - sobretudo se for possível ridicularizar sua estupidez - contra uma testemunha estúpida, parcial, inconstante, caso as pessoas pareçam inclinadas a ouvir. 230. De modo geral, é mais aceitável o que dizemos quando provocados do que quando tomamos a iniciativa. ${ }^{64}$ É que é maior a rapidez da inteligência que se revela na resposta, e o revide é próprio da natureza humana. De fato, damos a impressão de que nos manteríamos calados se não tivéssemos sido provocados; tal como, nessa mesma assembleia, ele não falou quase nada - pelo menos do que parecia mais espirituoso - que não fosse em resposta a uma provocação. Havia em Domício $^{65}$ tamanha seriedade, tamanha autoridade, que dava a impressão de que era preciso antes atenuar pelo humor que destruir pela impetuosidade o que era objetado por ele.

231. Observou então Sulpício: ${ }^{66}$

- E então, permitiremos a César, que, apesar de conceder a Crasso o primado nos gracejos, aplica-se muito mais a essa atividade, não explicar para nós a natureza e as fontes de todo esse gênero do jocoso, sobretudo quando reconhece haver tamanha força e utilidade no humor e na espirituosidade?

- Como não - respondeu Júlio -, se concordo com Antônio, quando afirma não existir nenhuma arte do humor?

232. Como Sulpício tivesse se calado nesse momento, observou Crasso:

- Como se houvesse alguma arte das próprias questões que Antônio já há muito está tratando. Há uma espécie de observação, segundo ele próprio disse, daqueles fatores que têm eficácia no discurso. Se eles pudessem tornar alguém eloquente, quem não seria eloquente? Quem não seria capaz de aprendê-los facilmente ou, em todo caso, de uma maneira ou de outra? Eu,

${ }^{64}$ Inst. 6.3.13: "Sem dúvida, a ocasião reside tanto nas circunstâncias (e a sua força é tal que frequentemente, com a sua ajuda, não só os incultos, mas também os rudes conseguem dizer coisas engraçadas) como nas palavras que alguém tenha dito previamente, porque todas essas frases são de longe muito mais agradáveis [uenustiora] quando proferidas nas respostas do que nos ataques.”

${ }^{65}$ Gneu Domício Enobarbo, orador contemporâneo de Crasso, com quem frequentamente debatia (cf. Brut. 164).

${ }^{66}$ Públio Sulpício Rufo, um dos personagens do diálogo, toma a palavra somente neste parágrafo do excurso sobre o riso. 
porém, creio que esses preceitos têm o poder e a utilidade, não de sermos levados pela arte a descobrir o que dizer, mas de confiarmos na correção do que alcançamos pela natureza, pelo estudo, pela prática, ou percebermos o erro, depois de aprendermos a que devemos atribuí-lo. 233. Por isso, César, também eu lhe peço que, se estiver de acordo, exponha o que pensa a respeito de todo este gênero do jocoso, para que nenhum aspecto da oratória, já que essa foi a vontade de vocês, pareça porventura ter sido omitido numa reunião desta importância e numa conversa tão rigorosa.

- No que me concerne - respondeu ele -, uma vez que exige a contribuição de um convidado, Crasso, não lhe darei motivo, com minha esquiva, para uma recusa futura. Embora não raro costume ficar estupefato com a impudência dos que gesticulam em cena enquanto Róscio ${ }^{67}$ está na plateia. De fato, quem é capaz de fazer um movimento sem que ele perceba seus erros? Do mesmo modo, eu, agora, enquanto Crasso me ouve, falarei pela primeira vez dos gracejos, e farei como o porco do provérbio, ${ }^{68}$ como dizem, ao ensinar aquele orador, a respeito do qual Cátulo, ${ }^{69}$ depois de ouvi-lo recentemente, disse que os demais deviam comer feno.

\section{Observou então Crasso:}

- Cátulo estava brincando, sobretudo porque discursa de uma forma tal, que parece dever ser alimentado com ambrosia. Mas vamos ouvir você, César, para vermos o desfecho da fala de Antônio.

E Antônio respondeu:

- Resta-me muito pouco a falar. Contudo, cansado já pelo esforço e pelo percurso de minha exposição, descansarei durante a fala de César, como se se tratasse de uma mais que oportuna hospedaria.

${ }^{67}$ Quinto Róscio Galo (c. 126-62), que Cícero defendeu em processo judicial por volta de 68 (Pro Roscio Comoedo), era considerado um ator de primeira linha já em seu tempo. De acordo com Smith (1867, p. 663), "os romanos consideravam que ele tinha alcançado uma perfeição tal em sua profissão, que se tornou comum chamar qualquer pessoa que se distinguisse particularmente em algum tipo de arte pelo nome de Róscio. Em sua juventude, Cícero foi instruído por Róscio; mais tarde, Róscio e ele frequentemente competiam para ver qual deles conseguia expressar um pensamento da maneira mais efetiva, o orador pela sua eloquência, ou o ator pelos seus gestos". Cf. ainda 2.242.

${ }^{68} \mathrm{O}$ trecho em latim (sus docebo oratorem...) faz referência ao ditado sus Mineruam docet ("um porco ensinando Minerva"), citado por Festo, 408 L: "in prouerbio est, ubi quis docet alterum cuius ipse inscius est", "ditado que se usa quando alguém ensina a outrem algo que, na verdade, não sabe” (Iso, 2002, p. 308).

${ }^{69}$ Quinto Lutácio Cátulo, cônsul em 78, e seu irmão César Estrabão (de Orat. 2.12 e 44) teriam se juntado ao diálogo dos oradores só no dia seguinte, perto da segunda hora, "quando Crasso ainda estava deitado e Sulpício, sentado ao seu lado, enquanto Antônio passeava com Cota pelo pórtico" (Scatolin, 2009, p. 197). 
- E contudo - observou Júlio -, você não considerará minha hospedagem muito generosa, pois, tão logo comece a sentir o gostinho, eu o expulsarei, obrigando-o a pegar novamente a estrada.

235. Mas, para que não os faça esperar por mais tempo, exporei muito brevemente o que penso acerca desse gênero como um todo. Cinco são as perguntas que se podem fazer acerca do riso: em primeiro lugar, qual é a sua natureza; em segundo, suas fontes; em terceiro, se cabe ou não ao orador querer provocar o riso; em quarto, em que medida; em quinto, quais são os tipos do risível. ${ }^{70}$ Quanto à primeira - qual a natureza do riso em si, de que modo é provocado, onde reside, como surge e manifesta-se tão repentinamente que, ainda que o desejemos, não somos capazes de contê-lo, e como toma conta ao mesmo tempo dos flancos, da boca, das veias, dos olhos, do rosto -, deixemos a cargo de Demócrito. ${ }^{71}$ Mas isso não diz respeito a esta conversa e, ainda que dissesse, não me envergonharia de não o saber, porque mesmo aqueles que dizem saber não o sabem. 236. Já quanto ao domínio e ao campo, por assim dizer, do risível - pois essa é a pergunta seguinte -, eles residem numa espécie de torpeza e deformidade. Ri-se unicamente, ou quase apenas, do que assinala e aponta alguma torpeza de maneira não torpe. ${ }^{72}$ E cabe, passando à terceira pergunta, cabe muito bem ao orador provocar o riso, seja porque a própria hilaridade granjeia a benevolência para quem a suscitou, seja porque todos admiram a sagacidade, muitas vezes colocada numa única palavra, sobretudo daquele que retruca, por vezes até do que provoca, seja porque debilita o adversário, porque o embaraça, porque o diminui, porque o intimida, porque o refuta, seja por mostrar que o próprio orador é educado, refinado, urbano, e sobretudo porque mitiga e alivia a tristeza e a seriedade, e não raro, pela brincadeira e pelo riso, refuta pontos delicados, que não são fáceis de rebater com argumentos. 237. Cumpre observar com extremo cuidado em que medida o risível deve ser empregado pelo orador, ponto que colocamos em quarto lugar, em nossa investigação. De fato, as pessoas não riem quando se ridiculariza uma perversidade enorme e atrelada a um crime ou uma enorme desgraça, ${ }^{73}$ pois desejam que os criminosos sejam feridos com uma força maior do que a do risível, não desejando que se zombe dos desgraçados, a

\footnotetext{
${ }^{70}$ A Institutio oratoria também apresenta cinco questões a respeito do humor, mais específicas, no entanto (6.3.28): "primum itaque considerandum est et quis $\{$ et $\}$ in qua causa et apud quem et in quem et quid dicat", ou seja, "deve-se considerar, antes de tudo, quem faz o discurso (29-30), a favor de que causa (31), na presença de quem (31), contra quem (32) e o que se diz (33-35)”.

${ }^{71}$ Cf. n. 20 da introdução.

${ }^{72}$ Sobre a torpeza, eis o que Quintiliano comenta (Inst. 6.3.83): “Ainda que suscite o riso, é extremamente indigno a um homem livre tudo o que for dito com torpeza ou brutalidade; foi o que fez (segundo me consta) certa pessoa que, ouvindo um homem de condição social inferior falar abertamente contra ele, disse: 'posso dar-lhe um soco e ainda processá-lo por ter a cabeça dura'. Aqui, de fato, é difícil saber se os ouvintes devem rir ou se indignar."

${ }^{73}$ Inst. 6.3.31: "Ninguém há de suportar um acusador divertido em uma causa hedionda, tampouco um defensor engraçado em uma causa que desperte misericórdia. Há ainda certos juízes demasiadamente austeros para tolerarem o riso de bom grado." Cf. ainda o parágrafo 33: "a brincadeira que tem por alvo os miseráveis é desumana".
} 
não ser que acaso se vangloriem. Deve-se respeitar sobretudo a afeição das pessoas, a fim de que não se ataque imponderadamente os que são estimados. ${ }^{74} 238$. Em primeiro lugar, então, cumpre empregar esta moderação quando se faz uma brincadeira. Assim, é muito mais fácil brincar com o que não é digno de muito ódio nem de grande misericórdia. Por isso, toda a matéria do ridículo reside nos vícios que se encontram na vida dos homens que não são estimados, nem desafortunados, nem aparentam serem merecedores de castigo em virtude de um crime. Quando recebem tratamento adequado, provocam o riso. 239. Há também uma belíssima matéria para brincadeiras na deformidade e nos defeitos corporais. Porém, investigamos o mesmo que é essencial investigar nas demais questões: a medida. A esse respeito, preceitua-se não apenas que não se brinque de maneira insípida, mas também que, ainda que surja a oportunidade de um gracejo engraçadíssimo, ${ }^{75}$ cumpre que o orador evite um e outro, a fim de que a brincadeira não incorra em bufonaria ${ }^{76}$ ou farsa. ${ }^{77}$ Logo compreenderemos com mais facilidade de que tipo são, quando passarmos aos gêneros do risível em si. Dois são, então, os gêneros de gracejos, dos quais um recebe tratamento segundo a matéria, outro, segundo a palavra. ${ }^{78} 240$. Segundo a matéria, se em algum momento se fizer alguma narração à maneira de uma anedota, como você fez em certa ocasião, Crasso,

${ }^{74}$ Inst. 6.3.28: "É importante considerar onde devemos empregá-lo. Na convivência familiar e na fala cotidiana, então, a postura atrevida será conveniente à gente ordinária, mas as posturas alegres convirão a todos. Nunca desejaríamos gerar ofensa, e longe de nós esteja o propósito de antes perder o amigo que a piada. $\mathrm{Na}$ verdade, nessa disputa forense eu preferiria que me concedessem o uso de termos brandos."

${ }^{75}$ É curioso o fato de o próprio César, mais adiante (274-6), reconhecer os "gracejos bastante absurdos" entre os gêneros do risível que podem servir ao orador. Quintiliano também o faz (Inst. 6.3.26): "Quanto a nós, podemos revelar nossas fraquezas de modo risível, fazendo observações um tanto absurdas, para retomar o termo de Cícero. Assim, as mesmas frases que são estúpidas se nos escapam quando estamos desprevenidos, são consideradas graciosas [uenusta] se as proferimos quando estamos dissimulando."

${ }^{76}$ Quintiliano também adverte seu orador ideal sobre os riscos no uso do humor forense (Inst. 6.3.8): "Ainda que o riso pareça coisa leviana, praticada por bufões e mimos, em suma, habitualmente pelos tolos, existe nele, contudo, uma força poderosíssima, à qual talvez seja praticamente impossível resistir." ${ }^{77}$ Sobre este parágrafo, cf. Corbeill, 1996, p. 21-2. É de reparar que, ao contrário do que esperaria o leitor moderno, a medida decorosa sugerida por Estrabão não consiste em evitar o uso de piadas sobre deformidades e defeitos físicos, mas em não se fazer gracejos insípidos ou absurdos. O exemplo por excelência desse tipo de humor na oratória ciceroniana encontra-se no In Vatinium, em que, ao interrogar Vatínio, que prestara testemunho no caso de Séstio, defendido pelo Arpinate em 56, Cícero zomba particularmente das escrófulas que apresentava no pescoço. Como bem observa Corbeill, 1996 passim, o pressuposto compartilhado com o público é o de que a um defeito físico corresponde um defeito moral.

${ }^{78}$ De acordo com o sexto livro da Institutio oratoria, o risível é criado a partir do que fazemos (25-26) ou dizemos (27-35), seguindo a dicotomia ciceroniana: in re et in uerbo. Quintiliano, contudo, dedica maior espaço à segunda dessas duas categorias, ao contrário do que ocorre em Cícero, que aborda mais de 20 tipos de gracejos baseados na matéria e apenas 8 tipos de gracejos baseados em palavras. 
contra Mêmio: ${ }^{79}$ disse que ele havia devorado o braço de Largo, porque havia brigado com ele em Tarracina por causa de uma amante. Toda a narração foi mordaz e, todavia, foi você mesmo quem a forjou. Acrescentou, como conclusão, que por toda a Tarracina, então, havia inscrições em todas as paredes com duas letras " $M$ " e três letras " $L$ ". Quando perguntou de que se tratava, um velho da província lhe teria respondido: "Mêmio, o mordaz, lasca o lombo de Largo". 241. Percebem como este gênero é gracioso, como é elegante, como é próprio do orador, quer tenhamos de fato algo que possamos narrar, ainda que seja preciso acrescentar algumas mentirinhas, quer o inventemos. A virtude deste gênero é a seguinte: de tal forma demonstrar os fatos, que se reproduza fielmente o caráter daquele sobre quem se narra, o seu modo de falar, todas as suas expressões; que eles pareçam, a quem ouve, produzir-se e acontecer naquele momento. ${ }^{80} 242$. Reside igualmente na matéria o risível que se costuma obter de uma imitação totalmente distorcida, como fez o mesmo Crasso: "Por sua nobreza, por sua família!". Que outro motivo havia para que a assembleia risse, senão aquela imitação da expressão e da voz? Porém, quando disse "por suas estátuas!" e, estendendo o braço, acrescentou um pequeno gesto, rimos muitíssimo. A este gênero pertence aquela imitação que Róscio fez do velho:

"Para ti, Antifonte, planto estas sementes", ${ }^{81}$ diz ele. "Quando o ouço, é a velhice que ouço". E todo o risível desse gênero é de tal natureza, que deve receber um tratamento extremamente cauteloso. De fato, se a imitação é excessiva, torna-se objeto dos mimos e dos pantomimeiros, tal como a obscenidade. ${ }^{82}$ É preciso que o orador insinue a imitação de tal forma que o ouvinte pense mais do que veja; que dê mostras de sua nobreza e pudor evitando a torpeza das palavras e a obscenidade da matéria. 243. Esses são, portanto, os dois gêneros do risível que residem na matéria. Eles são próprios dos gracejos contínuos, ${ }^{83} \mathrm{em}$ que se descrevem e se forjam os caracteres dos homens de tal forma que se perceba sua natureza por meio de alguma narração ${ }^{84}$ ou que se revelem, pela breve inserção de uma imitação, em algum

\footnotetext{
${ }^{79}$ Gaio Mêmio, tribuno da plebe em 111, era particularmente hostil à classe dos nobres, se tomarmos o testemunho de Salústio (Jug. 27).

${ }^{80}$ Inst. 6.3.33: "Convém evitar também que o que dizemos pareça petulante, insolente, deslocado no tempo e no espaço, ou premeditado e trazido pronto de casa".

${ }^{81}$ Provavelmente, fragmento de comédia perdida para nós.

${ }^{82}$ Inst. 6.3.29: "ao orador não convêm em hipótese alguma caretas e gestos afetados que nos mímicos costumam fazer rir. Assim, a mordacidade boba e teatral é completamente estranha à figura do orador: a obscenidade deve estar longe, de fato, não somente das palavras, mas principalmente de seu significado. Mesmo se surgir a chance de ser denunciada no adversário, esta não deve ser censurada de modo jocoso".

${ }^{83}$ Inst. 6.3.43: "Há também esse gênero que não consiste, por assim dizer, em disparar ditos cuja urbanidade vem expressa de modo breve, mas em uma espécie de ação que se desenvolve mais longamente, como a ação de Lúcio Crasso contra Bruto, que Cícero narra no segundo livro do De oratore e em alguns outros lugares".

${ }^{84}$ Inst. 6.3.39: "Narrar fatos engraçados [salsa] requer, antes de qualquer coisa, a sutileza e a eloquência próprias da oratória. Assim fizeram Cícero e Marco Célio, o primeiro ao narrar, na Defesa de Cluêncio,
} 
defeito particularmente apto para a zombaria. 244. Já o risível que reside na palavra é aquele que é provocado por certa agudeza de um termo ou pensamento. Porém, tal como naquele primeiro gênero, seja numa narração, seja numa imitação, é preciso evitar a semelhança com os mimos e os pantomimeiros, também neste é preciso que o orador guarde boa distância da mordacidade dos bufões. Como faremos, então, para distinguir Grânio, ${ }^{85}$ amigo íntimo de vocês, ou Vargula, ${ }^{86}$ meu amigo, de Crasso, de Cátulo, dos demais? Ora, no que me diz respeito, eu decididamente não sei a resposta, pois eles são mesmo mordazes - e Grânio, então, mais que todos. Penso que, em primeiro lugar, não devemos, sempre que surgir a oportunidade para alguma observação sarcástica, fazê-la necessariamente. ${ }^{87} 245$. Apresentouse uma testemunha de baixa estatura. Felipe pergunta: "Posso passar ao interrogatório?" Responde então o presidente do tribunal, às pressas: "Desde que seja curto e grosso". Nesse momento aquele retruca: "Você não terá motivo para me recriminar, pois curto ele já é". Isso foi engraçado... Porém, estava presente um juiz, Lúcio Áurifex, ele mesmo mais baixo ainda do que a testemunha. Todo o riso voltou-se contra o juiz. ${ }^{88} \mathrm{O}$ risível deu a impressão de ser inteiramente bufonesco. Logo, aquilo que pode se voltar contra quem não desejamos, por melhor que seja o dito, é, pela própria natureza, bufonesco. 246. Tal como esse Ápio, que se pretende mordaz - e ele é mesmo, embora por vezes caia nesse defeito bufonesco. Disse ele a Gaio Séxtio, um caolho, meu amigo: "Vou jantar em sua casa, pois vejo que há lugar para um”. Isso é bufonesco por dois motivos: porque o agrediu sem motivo e por ter falado, afinal de contas, algo que quadrava a todos os caolhos. ${ }^{89}$ As pessoas não riem tanto de tais coisas, por julgarem que foram planejadas. A resposta de Séxtio foi excelente e improvisada: "Lave

sobre Cepásio e Fabrício, o segundo, ao narrar sobre a disputa travada por Décimo Lélio e seu colega para chegar primeiro à sede da província. Em todos esses casos, não só a narração inteira deve ser elegante e graciosa, o maior atrativo [festiuissimum] é o que o orador acrescenta." Não há informações sobre a anedota que teve como protagonistas Décimo Lélio e o seu colega. Sobre o episódio de Cepásio e Fabrício, cf. Cic. Cluent. 58 e Quint. Inst. 6.3.40.

${ }^{85}$ Quinto Grânio (cf. 254; 281-282), amigo de Crasso e Antônio, foi pregoeiro público e ficou conhecido por seu tipo de humor agressivo (Cic. Planc. 14.33 e Fam. 9.15.2).

${ }^{86}$ Vargula, cf. 247, personagem desconhecido.

${ }^{87}$ Quintiliano também aborda a questão da moderação (Inst. 6.3.30): “Além disso, como quero que o orador fale de modo urbano, não quero, portanto, que ele demonstre forjar esse refinamento. Por essa razão, ele seguramente não dirá frases engraçadas [salse] todas as vezes que puder. Algumas vezes, preferirá desperdiçar um dito espirituoso a ver sua autoridade diminuída”.

${ }^{88}$ Quintiliano também alerta para os perigos das piadas que podem se voltar contra o juiz (Inst. 6.3.32): "Por vezes, costuma acontecer que aquilo que dizemos contra o adversário pode se aplicar ao juiz ou ainda ao nosso cliente, embora encontremos alguns oradores que não evitam sequer aquilo que pode voltar-se contra si mesmos. Assim fez Longo Sulpício, que, sendo ele mesmo horrendo, disse para um homem (contra quem pleiteava num julgamento a respeito da sua condição de liberto) que ele sequer tinha a aparência de um homem livre; ao que respondeu Domício Afro: 'você tem certeza absoluta, Longo, de que um homem mal-apessoado não pode ser um cidadão livre?’.”

${ }^{89}$ Inst. 6.3.34: "Este é um conselho que serve não só para o orador, mas para o homem: ao atacar alguém a quem seja perigoso ofender, faça-o de modo que não resulte em grandes inimizades ou 
as mãos e jante." 247. A consideração da ocasião, a moderação e o comedimento na própria mordacidade, bem como a parcimônia no uso dos ditos distinguirão o orador do bufão; e também o fato de que falamos com um propósito, não para parecer engraçados, mas para trazer algum benefício, ao passo que eles o fazem o tempo todo e despropositadamente. De fato, o que conseguiu Vargula, ao dizer, quando o candidato Aulo Semprônio, junto com seu irmão Marco, o abraçava: "escravo, espante as moscas!"90 Buscava o riso, que é, na minha opinião, o mais insignificante fruto da inteligência. Assim, controlaremos a ocasião de dizer algo engraçado por meio da prudência e da austeridade. Antes tivéssemos uma arte para tais coisas! Mas a natureza é soberana. ${ }^{91}$

248. Exponhamos agora, resumida e individualmente, os tipos que mais provocam o riso. Seja a primeira divisão a seguinte: o que se diz com graça apresenta alguns gracejos na matéria, outros, na palavra, e os homens se deleitam ao extremo se em algum momento o riso é provocado pela matéria e pela palavra conjuntamente. Mas lembrem-se do seguinte: quaisquer que sejam os tópicos que eu aborde de onde se pode extrair o ridículo, de quase todos eles é possível extrair pensamentos sérios. A única diferença é que se emprega a seriedade no que é honroso e austero, a brincadeira, no que é indecente e, por assim dizer, deformado. Com as mesmas palavras, por exemplo, poderíamos elogiar um escravo honesto e, se é patife, ridicularizá-lo. É engraçada aquela antiga observação de Nero ${ }^{92}$ sobre um escravo ladrão: "é o único para quem não há nada fechado ou trancado em casa", o mesmo que se costuma dizer sobre um bom escravo. ${ }^{93}$ Mas isso ocorre até com as mesmas palavras. Tudo, porém, nasce dos mesmos tópicos. 249. O que a mãe de Espúrio Carvílio ${ }^{94}$ disse a ele, que mancava fortemente devido a um ferimento sofrido em combate pela República e que, por isso, envergonhava-se de aparecer em público: "Por que não sai, Espúrio querido? a cada passo que der, deve se lembrar de suas virtudes" é belo e sério; o que Gláucia ${ }^{95}$ disse a Calvino, ${ }^{96}$

reparações humilhantes. Diz-se desastrosa também a carapuça que pode servir a um grande número de pessoas, ou seja, atacar povos inteiros, classes sociais ou as condições ou as crenças de muitos.” ${ }^{90}$ Aqui é preciso explicar a piada: os irmãos Aulo e Marco Semprônio eram conhecidos pelo cognomen Musca, idêntico ao substantivo latino comum para "mosca" (cf. Liv. 45.13).

${ }^{91}$ Cf. Cic. Or. 88.

${ }^{92}$ Cf. n. 26 da introdução.

${ }^{93}$ Quintiliano reporta a mesma anedota em Inst. 6.3.50: "há frases ainda que não apenas podem significar várias coisas, mas inclusive coisas opostas, como o que disse Nero acerca de um péssimo escravo: 'Em ninguém se confiava mais do que nele, nada estava trancado ou selado para ele'.'

${ }^{94}$ Há duas possibilidades para a identidade deste personagem: Espúrio Carvílio Máximo, cônsul em 293 e 272, ou Espúrio Carvílio Máximo Ruga, cônsul em 234 e 228.

${ }^{95}$ Gaio Servílio Gláucia, tribuno da plebe em 101, é descrito por Cícero como “o mais ímprobo dos homens que já existiram, mas extremamente agudo, esperto e engraçado" (cf. Brut. 224).

${ }^{96}$ Gaio Séxtio Calvino é mencionado em Brutus 130 como um orador de pensamento e linguagem sofisticados, ainda que sua saúde fosse precária (quando as dores nos pés lhe permitiam, ele não recusava causas). 
que manquejava: "qual é mesmo a antiga expressão? Será que claudica? Ora, ele craudica..." Isso é engraçado. E ambos foram tirados do que se pode observar no manquejar. ${ }^{98}$ Cipião ${ }^{99}$ falou seriamente: "Que há de mais ignavo do que este Névio?" Felipe, em contrapartida, falou de maneira bastante engraçada contra um homem que cheirava mal: "Noto que estou cercado por você." ${ }^{100}$ Mas a semelhança de uma palavra de letras trocadas une os dois tipos. 250. Os ditos baseados na ambiguidade são considerados extremamente argutos, ${ }^{101}$ mas nem sempre consistem numa brincadeira, muitas vezes também em algo sério. Públio Licínio Varo ${ }^{102}$ disse ao Africano, o Velho, ${ }^{103}$ que, num banquete, tentava ajustar uma coroa à cabeça que se rompia o tempo todo: "Não se admire se ela não lhe serve: você tem uma grande cabeça". Isso é a um só tempo louvável e honroso. Ora, do mesmo gênero é o seguinte

${ }^{97}$ O texto latino joga com os termos claudicat/clodicat. Norcio (1970, p. 378) atesta que a forma clodicare é correspondente plebeu de claudicare (coxear, mancar). Some-se a isto o fato de que o verbo, em contexto político, pode ser também interpretado com sentido pejorativo de "vacilar", "titubear", "hesitar".

${ }^{98}$ Uma tradução alternativa: "Será que está titubeando? Ora, ele titubeia o tempo todo!".

${ }^{99}$ Aulo Gélio (7.8.5) nos conta que certo Cipião deu o que falar em sua juventude e que Névio lhe dedicou versos não muito elogiosos. Ainda que seja impossível determinar com precisão a identidade de ambos os personagens, este Névio provavelmente se refere ao tribuno Marco Névio (184) ou ao autor do poema épico Bellum Punicum, Gneu Névio (c. 270-201), enquanto o Cipião aqui mencionado possivelmente seria Públio Cornélio Cipião Africano, o Velho, que venceu Aníbal em 202 e pôs fim à segunda guerra púnica. Ao longo do excurso sobre o riso, haverá outras menções ao nome Cipião: cf. 258, 260 (Maluginese), 262 (o Velho), 280 (pretor), 285 (o que deu cabo de Tibério Graco).

${ }^{100}$ No original uideo me a te circumueniri, o jogo de palavras latino se dá por paronomásia relacionada ao verbo circumueniri, cuja pronúncia poderia lembrar o substantivo bircus (bode). Daí a relação com o mau cheiro que suscitou a frase de Filipe.

${ }^{101}$ Quintiliano, no entanto, não encoraja os gracejos baseados na ambiguidade (Inst. 6.3.47-48): “Em primeiro lugar, não são convenientes aqueles baseados na anfibologia, nem as indiretas às quais os atelanos costumam recorrer, nem algumas expressões repetidas pelo populacho que, através da ambiguidade, quase sempre se convertem em palavrões. Igualmente inconveniente aquela frase que escapou a Cícero uma vez (ainda que não fosse durante um discurso), na ocasião em que um certo candidato (conhecido por ser filho de um cozinheiro) pedia, em sua presença, o voto de um outro: 'eu também pretendo sustentar-te'. Não porque toda e qualquer palavra de duplo sentido deva ser rejeitada, mas porque é raro que suas réplicas sejam agradáveis, a não ser quando são inteiramente apoiadas pelos próprios fatos." A conjunção quoque ("também”) e o vocativo coque (coquus, "ó cozinheiro”), que eram pronunciadas de forma parecida à época de Cícero, geram o chiste (para aqueles que conheciam a condição daquele candidato). Portanto, poder-se-ia entender a frase final literalmente: "eu também vou te favorecer", ou jocosamente, "eu, ó cozinheiro, vou te favorecer". Sendo a estratégia da paronímia difícil de conservar em língua portuguesa (como são os trocadilhos, em geral), optou-se pela ambiguidade semântica do verbo "sustentar" (prover alimentação/apoiar), que, embora apague o chiste por completo, recupera traços da representação do pai cozinheiro.

${ }^{102}$ Públio Licínio Varo, pretor em 208.

${ }^{103}$ Como já assinalado acima, a referência é a Públio Cornélio Cipião Africano, o Velho, que venceu Aníbal em 202. 
comentário: "A um Calvo basta, porque fala pouco". ${ }^{104}$ Resumindo: não há qualquer tipo de brincadeira de que não se possam extrair igualmente idéias sérias e austeras. 251. E é preciso observar também o seguinte: nem tudo que é engraçado é gracioso. De fato, o que pode ser mais engraçado do que um bufão? Mas rimos de sua boca, de sua expressão, da imitação que faz dos caracteres, de sua voz, enfim, de seu próprio corpo. Posso dizer que ele é divertido; não, porém, do modo que eu gostaria que um orador fosse, mas como um ator de mimos. Por isso, esse primeiro gênero, o que mais provoca o riso, não nos diz respeito: o rabugento, o supersticioso, o desconfiado, o fanfarrão, o tolo. Rimos de sua própria natureza. Tais personagens, costumamos criticá-las, não interpretá-las. 252. O segundo gênero reside na imitação, e é bastante engraçado, mas a nós só é permitido eventualmente, de maneira furtiva e rápida - caso contrário, não seria nada próprio de um homem livre; o terceiro, a contorção da boca, não é digno de nós; o quarto, a obscenidade, não é apenas indigno do fórum, mas mesmo de um banquete de homens livres. ${ }^{105}$ Retirados, então, tantos elementos do âmbito do orador, restam os gracejos, que parecem residir, conforme dividi anteriormente, na matéria ou na palavra. De fato, aquilo que é gracioso quaisquer que sejam as palavras que se empreguem, está contido na matéria; o que perde o sabor com a mudança das palavras tem toda a sua graça nelas.

253. As ambiguidades são particularmente agudas e concernem à palavra, não à matéria. Porém, raramente provocam muito riso: são antes elogiadas como belos e refinados ditos. Como aquele contra Tício: ${ }^{106}$ ele se entusiasmara no jogo da péla, e acreditava-se que havia quebrado estátuas sagradas durante a noite. Como ele não havia aparecido no Campo de Marte e seus amigos perguntavam por ele, Vespa Terêncio ${ }^{107}$ o desculpou, dizendo que quebrara um braço; como aquele do Africano, que se lê em Lucílio:

E então, Décio, que tal uma noz no espeto?, disse.

254. Como seu amigo Grânio, Crasso: "Não vale um sexto de asse". ${ }^{108} \mathrm{E}$, se querem saber, quem é chamado de mordaz sobressai-se principalmente neste gênero. Porém, outros elementos provocam maior riso. É verdade que a ambiguidade é apreciada por si mesma e, como disse anteriormente, de maneira extrema - pois parece próprio de alguém engenhoso

\footnotetext{
${ }^{104}$ Para Norcio (1970, p. 380), a facécia consiste em conferir ao adjetivo caluus também o significado de "parco em palavras" ou "pobre de ideias", para investir contra alguém que respondia laconicamente ou, simplesmente, contra um orador ruim. Já para Iso (2002, p. 317), a frase "Caluus satis est, quod dicit parum" é problemática, tanto porque Caluus pode ser adjetivo ou cognomen quanto porque o sintagma satis est pode ter o significado de "comer suficientemente". A tradução que José Iso propõe é a seguinte: "Calvo come o suficiente porque fala pouco".

${ }^{105}$ Idênticas, ainda que enumeradas de modo mais conciso, são as restrições de Quintiliano (Inst. 6.3.29). ${ }^{106}$ Sexto Tício, tribuno da plebe em 99, é descrito em de Orat. 2.48 como "cidadão sedicioso e agitador" (cf. ainda 265).

${ }^{107}$ Vespa Terêncio: única referência a este nome em toda a obra de Cícero (Bailey, 1996, p.60).

108 Asse: unidade que servia de termo de comparação para as moedas, pesos e medidas de Roma; moeda romana.
} 
ser capaz de fazer o sentido de uma palavra passar a outro, diferente do entendimento dos demais - mas provoca mais admiração do que riso, a não ser que, eventualmente, incida também em outro gênero de risível.

255. Passarei tais gêneros em revista, é claro. Ora, como vocês sabem, é conhecidíssimo o gênero de risível em que esperamos uma coisa mas se fala outra. ${ }^{109}$ Esse nosso equívoco provoca o riso em nós mesmos. Se ele é misturado também à ambiguidade, torna-se muito divertido, como é o caso daquele homem aparentemente misericordioso da peça de Nóvio, ${ }^{110}$ que vê um condenado por dívida sendo levado. Ele pergunta: "Ele foi adjudicado por quanto?" - "Mil moedas." Se tivesse acrescentado apenas "Pode levar!", teríamos aquele gênero de risível que contraria as expectativas. Porém, como acrescentou: "Não tenho nada a acrescentar, pode levar!", acrescendo outro gênero ambíguo de ridículo, foi divertidíssimo - pelo menos é o que me parece. Este gênero é extremamente encantador quando, numa altercação, roubamos uma palavra do adversário e com ela atacamos aquele mesmo que nos provocou, como Cátulo fez com Felipe. ${ }^{111}$

256. Ora, como vários são os tipos de ambiguidade, a respeito dos quais há uma teoria bastante precisa, convirá atentar às palavras e ficar à sua espreita. Nesse gênero, apesar de evitarmos as ambiguidades mais inexpressivas - pois devemos cuidar para que o dito não seja considerado afetado -, falaremos inúmeras delas com agudeza. Outro gênero é aquele que apresenta uma pequena mudança na palavra e que, quando baseado numa letra, os gregos chamam de paronomasía, como, por exemplo, "Senhor Notável, Senhor Instável", ${ }_{112}$ de Catão. Ou, como o mesmo Catão, quando disse a alguém: "vamos divagar por aî?", e o outro respondeu: "Qual a necessidade do 'di'?” Ele retrucou: "Ora, qual a necessidade de

${ }^{109}$ Inst. 6.3.24: "O terceiro tipo [de gracejo] consiste, como também diz Cícero, em contrariar as expectativas; em tomar de maneira diversa à pretendida os ditos de outrem e em quaisquer frases que não se refiram a nós nem aos outros: por essa razão as chamo de 'intermediárias' [media]." Quintiliano é o primeiro a propor uma classificação tríplice para o emprego do humor: o riso é extraído ou de outros, ou de nós mesmos ou de coisas intermediárias (anúncio em 22-24, desenvolvimento entre 71 e 100). Viljamaa (1994, p. 86) defende uma lógica intrínseca nas tripartições que Quintiliano propõe: os três lugares de onde podemos extrair o riso corresponderiam exatamente às suas três sedes: a) derisus (“escárnio", \$7); b) subabsurda ("besteirol”, \$23); c) industria depranatum ("expectativas contrariadas", \$6). Assim, o riso criado a partir dos outros seria baseado na teoria da superioridade (i.e., no prazer de humilhar alguém, de reconhecê-lo inferior); aquele a partir de nós mesmos, baseado nos absurdos; e, finalmente, o riso gerado a partir das coisas intermediárias, que se explica pela teoria do desapontamento (interpretar as palavras de outra maneira que não a pretendida).

${ }^{110}$ Nóvio, contemporâneo dos principais protagonistas do diálogo, foi autor de atelanas (gênero teatral cômico originário da região da Campânia), das quais nos restaram apenas títulos e poucos fragmentos. Esta é a primeira das três citações cômicas de Nóvio (cf. 279, 285).

${ }^{111}$ Cf. 220.

112 Marco Fúlvio Nobilior, o "notável”, cônsul em 189, torna-se, para Catão, o Censor, M. Fúlvio Mobilior, o "instável". Iso (2002, p. 320) o identifica como Quinto Fúlvio Nobilior, vencedor da batalha de Ambrácia e protetor de Ênio. 
'ti’?" Ou aquela estipulação do mesmo Catão: "Se você é despudorado do cabo ao rabo". ${ }^{113}$ 257. Também a explicação de um nome apresenta sagacidade quando se converte em motivo de riso a etimologia do nome de alguém, como eu disse há pouco tempo, por exemplo: Númio, ${ }^{114}$ o distribuidor de dinheiro, tal como Neoptólemo, diante de Troia, encontrou seu nome no Campo de Marte. ${ }^{115} \mathrm{E}$ tudo isso pertence ao domínio da palavra. Muitas vezes, também, insere-se um verso graciosamente ${ }^{116}$ - seja como ele é, seja com uma pequena alteração - ou uma parte de um verso, como o de Estácio, ${ }^{117}$ citado por Escauro ${ }^{118}$ num momento de ira (há quem diga que foi desse episódio que nasceu sua lei da cidadania, ${ }^{119}$ Crasso):

Silêncio! Que gritaria é essa? Quem não tem mãe nem pai

Tem tanta arrogância? Parem com essa soberba!

${ }^{113}$ Quintiliano julga insípidos os gracejos baseados na paronomásia (Inst. 6.3.53-54): "Esse procedimento, no entanto, é tão insípido quanto a formação de nomes próprios a partir da adição, subtração ou alteração de letras, como no caso de Acísculo, que havia firmado um pacto e foi chamado Pacísculo; ou de Plácido, cujo temperamento era um tanto amargo e foi chamado Ácido, ou ainda de Túlio, que, por ser ladrão, foi chamado Tólio" (são todos jogos de palavras: o nome Pacisculus foi criado a partir do verbo paciscor, que significa "estipular um pacto". Tollius se refere ao verbo tollo, que significa "tirar", "tomar", "roubar"). A esse respeito, cf. Suet., Tib. 42, acerca dos apelidos dos imperadores romanos que abusavam do vinho: "In castris tiro etiam tum propter nimiam uini auiditatem pro Tiberio 'Biberius', pro Claudio 'Caldius', pro Nerone 'Mero' uocabatur.”

${ }^{114}$ O nome próprio "Númio" invoca o substantivo comum nummus, "moeda" em latim, com alusão à corrupção eleitoral.

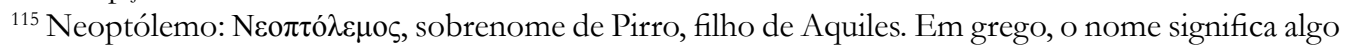
como "novo guerreiro", porque ele era ainda muito jovem quando chegou a Troia, $\mathrm{Il}$. 19.327, $\mathrm{Od}$. 11.506. Iso (2002, p. 320) lembra que o Campo de Marte era o local onde as eleições eram celebradas. ${ }^{116}$ Inst. 6.3.86: "Cícero dissimulou na ocasião em que, tendo Sexto Anal (como testemunha) prejudicado o réu que Cícero defendia e o acusador insistisse sem parar na frase: 'se puder, Marco Túlio, diga algo sobre este Sexto Anal!' Ele então começou a recitar um verso do sexto livro dos Anais de Ênio: 'Quem poderia arrolar as tão grandes causas de uma guerra?'."

${ }^{117}$ Ainda que Iso (2002, p. 321) - sem dizer por quê - descarte a possibilidade de se tratar do célebre comediógrafo Cecílio Estácio (230-168), Norcio (1970, p. 384) atribui a autoria da citação a este Cecílio, mas não identifica a obra da qual provém.

${ }^{118}$ Marco Emílio Escauro, cônsul em 115 (cf. 265, 280 e 283). Os versos de Estácio poderiam representar o enfado de Escauro com a pretensão dos itálicos em obter a cidadania romana.

${ }^{119}$ Trata-se da Lex Licinia Mucia, promulgada em 95, durante o consulado de Crasso e Quinto Múcio Cévola, o Pontífice, segundo a qual os itálicos, que se comportavam como cidadãos romanos sem, de fato, terem sido reconhecidos como tal, seriam removidos dos 35 clãs tradicionais de Roma. A lei Licínia pode ter contribuído para a motivação das guerras sociais, que começaram apenas três anos depois, como lembra Iso (2002, p. 321). 
De fato, no caso de Célio, ${ }^{120}$ também foi extremamente útil a sua causa, Antônio, aquela citação, quando ele, que tinha um filho bastante dado aos prazeres, testemunhou que $\mathrm{o}$ dinheiro provinha dele. Quando já se afastava, você disse:

Está vendo que o velho foi roubado em trinta minas?

258. Nesse gênero englobam-se também os provérbios, ${ }^{121}$ como aquele de Cipião, ${ }^{122}$ por exemplo, quando Aselo ["asninho"] se vangloriava de ter percorrido todas as províncias enquanto servia no exército. Ele disse: "Toca o asninho", e por aí vai. Por isso, pelo fato de não se conseguir manter a mesma graça quando se mudam as palavras, deve-se considerar que tais gracejos se baseiam não na matéria, mas nas palavras. 259. Há também um gênero baseado na palavra não destituído de graça, que tem origem quando se parece entender algo literalmente, não de acordo com a ideia. ${ }^{123} \mathrm{O}$ Tutor ${ }^{124}$ um mimo antigo extremamente engraçado, baseia-se inteiramente nesse gênero. Mas afasto-me dos mimos: quero apenas que o gênero desse tipo de risível seja ilustrado por um exemplo distinto e conhecido. Pertence a esse gênero aquele gracejo que você fez há pouco tempo, Crasso, para aquele homem que lhe perguntou se lhe seria inconveniente se fosse a sua casa antes do amanhecer. Você respondeu: "você não será inconveniente". Ele perguntou: "Você vai mandar, então, que o acordem?". E você: "Como eu disse, você não será inconveniente..." 260. Também pertencente a esse gênero é aquele antigo gracejo: contam que o famoso Cipião Maluginense, ${ }^{125}$ quando

\footnotetext{
${ }^{120}$ Este Célio provavelmente é Gaio Célio Caldo, tribuno da plebe em 107 e cônsul em 94.

${ }^{121}$ Quintiliano elogia o emprego de provérbios parodiados (Inst. 6.3.98): “O mesmo [sc. o benefício de favorecer a urbanidade] vale para provérbios oportunamente adaptados, como o que disseram a um patife que, caído no chão, pedia ajuda para se reerguer: 'Quem não te conhece que te levante'.' ${ }^{122}$ Trata-se de Públio Cornélio Cipião Emiliano Africano, o jovem, cônsul em 147 e censor em 142. Durante sua censura, Cipião expulsou Tibério Cláudio Aselo da ordem equestre, rebaixando seu status social. Para Norcio (1970, p. 386), o provérbio é quase certamente uma versão do provérbio

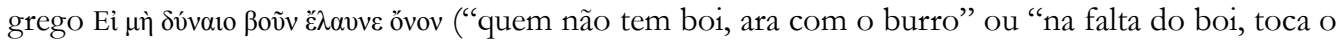
asno”), e pretendia evidenciar as parcas habilidades militares de Aselo.

${ }^{123}$ Quintiliano também aborda o humor da interpretação literal (Inst. 6.3.85-87): “O riso é ainda mais farto no que tange à simulação e à dissimulação, técnicas muito próximas e quase iguais, mas na primeira finge-se acreditar piamente em determinada coisa, na segunda finge-se entender pouco aquilo que o outro faz ou diz. [...] A ambiguidade oferece à dissimulação, sem dúvida, inúmeras oportunidades, como ocorreu a Cascélio, que, ouvindo um consulente dizer 'quero dividir o navio com alguém', respondeu 'vai arruiná-lo'. Mas a compreensão das palavras costuma ser modificada também de outro modo, quando, por exemplo, se transforma uma situação tensa em uma situação amena. Foi o que fez um sujeito ao ser interrogado sobre sua opinião acerca de um outro, que tinha sido flagrado em adultério, dizendo: 'Acho que ele foi muito lerdo'.'

${ }^{124} \mathrm{O}$ mimo foi um gênero teatral menos prestigiado, importado da Magna Grécia. Em solo romano, assumiu as cores de comédia de costumes, na qual os atores atuavam sem máscaras nem calçado especial. Não há informação sobre o mimo (Tutor) ao qual César se refere aqui.

${ }^{125}$ Marco Cornélio Cipião Maluginense, pretor em 176.
} 
anunciava que Acidino ${ }^{126}$ fora eleito cônsul pela sua centúria e o arauto lhe perguntou: "O que me diz de Lúcio Mânlio?" Ele respondeu: "considero-o um homem honesto e um cidadão ilustre.” Engraçada também é a resposta de Lúcio Nasica ${ }^{127}$ ao censor Catão. ${ }^{128}$ Quando este lhe perguntou: "Responde-me de bom grado: tens esposa?" Ele respondeu: "Tenho, mas certamente não de bom grado.” Esses gracejos são ou inexpressivos ou, quando se espera outra coisa, divertidos. ${ }^{129}$ De fato, por natureza, como disse anteriormente, deleitamonos com nosso próprio erro. Por isso, quando somos como que enganados por nossa expectativa, rimos. 261. Também se baseiam nas palavras os gracejos que são derivados de um discurso mudado, ${ }^{130}$ ou do translado ${ }^{131}$ de uma única palavra, ou da inversão do sentido das palavras. ${ }^{132}$ Da mudança, como, por exemplo, Rusca, ${ }^{133}$ certa vez, quando propôs a lei etária, ${ }^{134}$ Marco Servílio, ${ }^{135}$ o opositor, lhe perguntou: "diga-me, Marco Pinário, quando eu falar contra você, você falará mal de mim, como fez com os demais?" Ele respondeu: "Você colherá o que plantou." 262. Do translado, como, por exemplo, quando o famoso Cipião, o Velho, ${ }^{136}$ disse aos coríntios, que lhe prometiam erigir uma estátua no lugar onde havia estátuas de outros comandantes, que não gostava de esquadrões de cavalaria. Inverte-se o

${ }^{126}$ Lúcio Mânlio Acidino Fulviano foi eleito cônsul em 179 (Liv. 40.43). Nas eleições dos magistrados, o chefe da centúria (neste caso, Cipião Maluginense) era responsável por anunciar o nome do candidato escolhido pela centúria. Cipião disse o nome de Acidino (por meio somente do cognomen, sem dizer o praenomen e o nomen) e o arauto, achando que Lúcio Mânlio fosse uma pessoa distinta de Acidino, lhe pediu informação sobre Lúcio Mânlio (Norcio, 1970, p. 387).

${ }^{127}$ Lúcio Pórcio Nasica toma a expressão ex tui animi sententia ao pé da letra, quando a pergunta de Marco Pórcio Catão (cônsul em 195 e censor em 184) era apenas uma fórmula ritualística. Segundo Iso (2002, p. 323), a pergunta, na cerimônia do censo, tinha sentido, pois os solteiros pagavam um imposto especial, o aes uxorium ("a taxa das esposas"). Se tomarmos o testemunho de Aulo Gélio (4.20.10) em conta, a piada custou caro a Nasica, que foi relegado pelo severo censor entre os aerarii (ou seja, cidadãos sine suffragio, sem direito a voto).

${ }^{128}$ Marco Pórcio Catão, o Censor ou o Velho (234-149).

${ }^{129}$ Inst. 6.3.84: "Falta falar ainda das técnicas de contrariar a expectativa e de tomar em outro sentido aquilo que se diz, as quais, entre todas as formas de suscitar o riso, são as mais graciosas."

${ }^{130}$ Immutata oratio, termo latino para a figura retórica da $\dot{\alpha} \lambda \lambda \eta \gamma$ opía (alegoria).

${ }^{131}$ Translatio, termo latino para a figura retórica da metáfora (significação figurativa).

${ }^{132}$ Inuersione verborum, glosa latina para a figura retórica da ironia. Em duas passagens (Inst. 6.2.15 e 8.6.54), Quintiliano declara que a ironia consiste em interpretar as palavras ao contrário do que parecem significar. Cf. também o parágrafo 269 deste excurso.

${ }^{133}$ Marco Pinário Rusca, pretor em 181 (Liv. 40.18).

${ }^{134}$ A lei etária (Lex Vilia Annalis) estabelecia uma idade mínima para os candidatos à magistratura em Roma.

${ }^{135}$ Iso (2002, p. 324) lembra que a proposta de uma lei - rogatio -, como possível objeto de um discurso deliberativo, podia ter defensores e detratores. Cícero foi dissuasor da lei agrária que, em 63, o tribuno da plebe Rulo submeteu às instâncias de César. Não há mais informações sobre a identidade de Marco Servílio.

${ }^{136}$ O mesmo Públio Cornélio Cipião Africano, o Velho, que venceu Aníbal em 202 (cf. 249-250). 
sentido das palavras como, por exemplo, quando Crasso defendeu Aculeão perante o juiz Marco Peperna, enquanto Lúcio Élio Lâmia, um homem deformado, como sabem, defendia Gratidiano contra Aculeão. Como ele o interrompia de maneira desagradável, Crasso disse: "Ouçamos esse rapaz bonitinho." Quando riram dele, Lâmia retrucou: "Não pude moldar minha beleza, mas pude moldar minha inteligência." Então Crasso disse: "Ouçamos esse orador expressivo." Riram muito mais ainda dele. Também o gênero seguinte é muito gracioso, tanto nos pensamentos austeros como nos gracejos - de fato, disse há pouco que uma é a matéria da brincadeira, outra, a da seriedade, mas que é um só o método dos gêneros e dos tópicos. 263. Orna, então, sobremaneira o discurso o uso de palavras de sentido oposto. Muitas vezes esse mesmo gênero é também espirituoso. Como, por exemplo, quando o famoso Sérvio Galba ${ }^{137}$ submeteu a Lúcio Escribônio, ${ }^{138}$ tribuno da plebe, uma lista de juízes composta de seus amigos, e Libão disse: "Mas quando é que você vai sair de seu triclínio, Galba?" Ele respondeu: "Quando você sair do quarto alheio." 139 Não dista muito desse gênero nem mesmo o que Gláucia ${ }^{140}$ disse a Metelo:"141 "Você tem uma granja no território de Tíbur, um rebanho no Palatino." ${ }^{142}$

264. Considero ter abordado os gêneros de gracejos baseados nas palavras. Os baseados na matéria são mais numerosos e, como disse anteriormente, provocam mais riso. Entre eles encontra-se a narração, algo bastante difícil, pois é preciso apresentar e colocar diante dos olhos elementos que não apenas pareçam verossímeis, o que é próprio da narração, mas que também sejam um pouco torpes, o que é próprio do risível. Por uma brevidade maior, sirva de exemplo a narração de Crasso sobre Mêmio que mencionei

\footnotetext{
${ }^{137}$ Sérvio Sulpício Galba, eminente orador e cônsul em 144.

${ }^{138}$ Lúcio Escribônio Libão, tribuno da plebe em 149.

${ }^{139} \mathrm{O}$ chiste de Galba está baseado nos termos latinos triclinium (um móvel que acomoda até três pessoas durante as refeições romanas, invocado por Libão) e cubiculum ("quarto", retorquido por Galba). As leis romanas davam ao cidadão implicado em processo judicial a oportunidade de escolher o juiz que desejasse. Galba, valendo-se desse direito, escolhe como juízes alguns de seus amigos e, por isso, Libão o censura. Segundo Galba, porém, Libão lhe apresentava uma lista de elegíveis na qual constavam os maridos de suas amantes (cf. Iso, 2002, p. 325; Norcio, 1970, p. 388).

${ }^{140}$ Gaio Servílio Gláucia, tribuno da plebe em 101 (já mencionado no parágrafo 249).

${ }^{141}$ Quinto Cecílio Metelo Numídico, cônsul em 109, e comandante da primeira fase da guerra contra Jugurta.

${ }^{142}$ Tíbur, atual Tivoli, cidade na região metropolitana de Roma. Palatino, uma das sete colinas de Roma, em cuja encosta foi construído o fórum romano, sede do senado e do governo republicano. O texto original traz a seguinte formulação: villam in Tiburti, cortem in Palatio. Em latim, o substantivo cohors (cohortem, no acusativo) geralmente denota um séquito ou comitiva (daí cohors principis, que originou o termo "corte" nas línguas românicas), enquanto a forma contraída cortem geralmente denota o pátio traseiro de uma casa de campo, onde costumam ficar os animais. Gláucia pretendia dizer que os apoiadores políticos de Metelo tinham o mesmo valor que a criação de sua pocilga.
} 
anteriormente. ${ }^{143} \mathrm{E}$ atribuamos a esse gênero também as narrações dos apólogos. ${ }^{144} 265$. Pode-se obter alguma graça também da história,${ }^{145}$ como quando Sexto Tício afirmou ser uma Cassandra. ${ }^{146}$ Antônio the respondeu: "sou capaz de citar seus vários Ájax Oileus". ${ }^{147}$ Há também um gracejo originado numa semelhança, que envolve uma comparação ou uma espécie de retrato. A da comparação é como quando o famoso Galo testemunhou certa vez contra Pisão, ${ }^{148}$ afirmando que este dera uma soma inumerável de dinheiro a Mágio, seu intendente, e Escauro o refutou alegando a pobreza de Mágio. Pisão respondeu: "Você está enganado, Escauro, pois não alego que Mágio guardou o dinheiro, mas que, tal como um homem nu colheria nozes, o guardou em seu ventre." Tal como aquele gracejo de Marco Cícero, o Velho, ${ }^{149}$ pai de nosso excelente amigo: "Nossos conterrâneos são semelhantes aos escravos sírios: quanto mais grego sabem, mais imprestáveis são." 266. Também rimos muito dos retratos, que quase sempre são direcionados contra uma deformidade ou algum defeito corporal com uma semelhança a algo ainda mais torpe, como aquele meu contra Hélvio Mância: ${ }^{150}$ "Mostrarei agora como você é." Quando ele respondeu: "Mostre, por favor", eu apontei para um gaulês deformado que estava pintado no escudo címbrico de Mário, perto das lojas novas, com a língua para fora, com as bochechas flácidas. Todos riram: nada era tão parecido com Mância! Tal como eu disse a Pinário, ${ }^{151}$ uma testemunha que torcia a boca enquanto falava: se quisesse falar alguma coisa, que primeiro quebrasse a noz em sua

1432.240 .

${ }^{144}$ Inst. 6.3.44: "Costuma-se obter êxito semelhante [ao gracejo de Crasso contra Bruto] também com a exposição de fábulas e, algumas vezes, até de certas anedotas históricas."

${ }^{145}$ Tanto Cícero como Quintiliano falam em "história" ou "acontecimentos históricos" ao incluir um exemplo mitológico em seus tratados (Inst. 6.3.98): "Auferir urbanidade até de acontecimentos históricos é sinal de erudição, como fez Cícero quando, ao interrogar uma testemunha no julgamento de Verres, Hortênsio lhe disse: 'Não entendo esses enigmas'; 'mas deveria', falou Cícero, 'já que a Esfinge está na sua casa' (de fato, ele tinha aceitado como presente de Verres uma Esfinge de bronze caríssima)." ${ }^{146}$ Sexto Tício (cf. 253) se refere à princesa de Troia, filha de Príamo e Hécuba, cujas previsões sobre o futuro (incluído o destino trágico da sua cidade natal) eram desacreditadas por todos devido ao castigo que Apolo lhe impingiu por rejeitá-lo.

${ }^{147}$ Ájax Oileu: na peça As Troianas (v. 70), Eurípides narra que Cassandra foi violentamente atacada no templo da deusa Atena, após a tomada de Troia. A violação de Cassandra por Ájax Oileu foi tema popular na iconografia grega (LIMC I.1, p. 339). Ao que parece, Antônio pretendia expor a homossexualidade de Tício publicamente.

${ }^{148}$ Possivelmente, Lúcio Calpúrnio Pisão Cesonino, cônsul em 58.

${ }^{149}$ Marco Cícero, o Velho.

${ }^{150}$ Inst. 6.3.38: "É raro que [o risível] chegue a ficar evidente aos olhos, como aconteceu a Gaio Júlio, que era continuamente incomodado por Hélvio Mância e disse: "então vou mostrar como você é". Como este, perguntando, claramente insistia que se mostrasse, afinal, como ele era, Gaio Júlio apontou com o dedo a imagem de um guerreiro gaulês pintada em um escudo címbrico, com quem Mância pareceu então muito semelhante. Havia tabernas em volta do fórum e aquele escudo tinha sido colocado ali como uma indicação."

151 Tito Pinário. Não confundir com Marco Pinário Rusca, mencionado no parágrafo 261. 
boca! 267. Há também aqueles que são exagerados de uma maneira extraordinariamente incrível, seja para diminuir, seja para aumentar, tal como você, Crasso, numa assembleia popular: "Mêmio cria-se tão alto que, quando descia ao fórum, abaixava a cabeça ao passar pelo arco de Fábio." Também a esse gênero pertence aquilo que, segundo se diz, Cipião, irritado com Gaio Metelo, ${ }^{152}$ teria dito em Numância: "Se a mãe dele desse à luz um quinto filho, daria à luz um asno!”153 268. Ocorre uma alusão sagaz quando se explica algo obscuro e misterioso por meio de um detalhe e, muitas vezes, de uma única palavra, como quando Públio Cornélio, ${ }^{154}$ homem ganancioso, segundo se cria, e propenso ao roubo, mas bastante corajoso e bom comandante, agradeceu a Gaio Fabrício ${ }^{155}$ por lhe ter dado seu voto para o consulado apesar de ser seu inimigo, sobretudo em meio a uma guerra grande e séria. Ele respondeu: "Você não tem por que me agradecer se preferi ser pilhado a ser vendido". Tal foi o caso da resposta do Africano a Aselo, quando este o criticava por aquela purificação infausta: "Não se espante, pois foi quem o livrou de ser recenseado entre os erários que concluiu a purificação e imolou o touro."

269. Também a ironia é refinada, ${ }^{156}$ quando se fala uma coisa e se pensa outra, não daquele modo de que falei anteriormente, quando se diz o contrário do que se pensa, como Crasso fez com Lâmia, ${ }^{157}$ mas quando associamos brincadeiras de tom sério a toda a nossa maneira de falar, quando se pensa uma coisa e se fala outra, como, por exemplo, o nosso Cévola

${ }^{152}$ Gaio Cecílio Metelo Caprário, cônsul em 113, quarto filho de Metelo Macedônico, era o mais simplório dos quatro irmãos, que já não primavam pela inteligência (cf. Norcio, 1970, p. 392).

${ }^{153}$ Quintiliano conta anedotas ligeiramente diferentes, porém na mesma sequência (Inst. 6.3.67): “Ou não é através da hipérbole que podemos dizer um sem-número de expressões? Eis o que pronunciou Cícero sobre um homem muito alto: ‘ele deve ter batido a cabeça no arco de Fábio', e o que Públio Ópio disse sobre a família de Lêntulo (cujos filhos repetidamente cresciam menos do que os pais): 'de tanto nascer, hão de se extinguir'."

${ }^{154}$ Públio Cornélio Rufino, cônsul em 290 e 277, foi um general destemido, mas ganancioso demais (Norcio, 1970, p. 392).

${ }^{155}$ Gaio Fabrício Luscino, cônsul em 282 e 278, famoso por sua integridade moral e simplicidade no estilo de vida.

${ }^{156}$ Em seu tratado, Quintiliano também apresenta conjuntamente as figuras da alegoria, da metáfora e da ironia, mas o faz na ordem inversa, adotando os termos gregos transliterados para o alfabeto latino (Inst. 6.3.68-69): "E quanto à ironia [ironia]? Não é verdade que mesmo aquela proferida do modo mais sério, tem algo de jocoso? Afro usou-a com urbanidade quando disse a Dídio Galo (que tinha solicitado o governo da província com o maior empenho e, depois de obtê-lo, reclamava como se tivesse sido obrigado a aceitá-lo): ‘Que tal dessa vez fazer algo a favor do governo?’ Cícero também se valeu da metáfora [metaphora] quando foi anunciada a morte de Vatínio, proveniente, dizia-se, de fonte pouco segura: 'Enquanto isso, desfrutarei do benefício da dúvida', ele disse. Ele mesmo, através da alegoria [per allegorian], dizia de Marco Célio (cujo desempenho era melhor na acusação do que na defesa) que ele tinha uma ótima direita e uma péssima esquerda".

${ }^{157}$ Cf. 262. 
fez com o famoso Septumuleio Anagnino, ${ }^{158}$ que fora pago em ouro pela cabeça de Gaio Graco $^{159}$ e lhe solicitava que o levasse para a Ásia como intendente. Ele respondeu: “O que você quer, insano? Tamanha é a multidão dos cidadãos desonestos, que posso lhe assegurar que, se permanecer em Roma, em poucos anos alcançará maiores riquezas.” 270. Fânio, ${ }^{160} \mathrm{em}$ seus Anais, afirma que Africano Emiliano ${ }^{161}$ se dedicou a esse gênero, e o chama de "irônico"

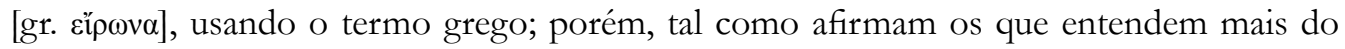
assunto, considero que Sócrates superou em muito a todos nesta ironia e dissimulação por seu encanto e refinamento. Trata-se de um gênero extremamente elegante e que mistura o humor à seriedade, adequado não apenas aos pronunciamentos oratórios, mas também às conversas refinadas. 271. E não há dúvida de que tudo isso que estou a discutir sobre os gracejos é um condimento que serve tanto para as ações forenses como para qualquer conversa. ${ }^{162}$ De fato, como se lê em Catão ${ }^{163}$ - que refere muitos dos gracejos que citei como exemplo - parece-me muito espirituoso o que Gaio Publício costumava dizer: "Públio Múmio é um homem para qualquer ocasião." 164 Assim, claramente a situação é tal, que não existe

${ }^{158}$ Segundo Valério Máximo (9.4.3), o cônsul Opímio ofereceu uma recompensa pela cabeça de Gaio Graco e Lúcio Septumuleio Anagnino. Traindo a amizade com Gaio, não apenas cortou sua cabeça, mas a pendurou em uma lança para exibi-la pelas ruas de Roma. Isto ocorreu em 121, ano em que Cévola deveria se apresentar para o governo de sua província na Ásia.

${ }^{159}$ Gaio Semprônio Graco, tribuno da plebe em 123, neto de Cipião Africano, o Velho. Com o irmão Tibério, propôs uma agenda de reformas políticas que desagradou aos optimates, ala conservadora do senado romano.

${ }^{160}$ Gaio Fânio foi historiador e, tendo lutado na terceira guerra púnica ao lado de Tibério Graco (em Cartago, no ano de 146 AEC), sua obra provavelmente serviu de fonte para que Plutarco escrevesse sobre os Gracos em Vidas Paralelas. Cícero (Brut. 99) nos fala de dois Gaios Fânio contemporâneos aos irmãos Graco: o primeiro, orador e cônsul em 122, foi genro de Lélio; o segundo seria esse historiador. ${ }^{161}$ Públio Cornélio Cipião Emiliano Africano, o Jovem, cônsul em 147 e censor em 142 (cf. 258).

${ }^{162}$ Quintiliano também ressalta o valor da conversação externa ao fórum para o cultivo do tipo de humor que interessa à oratória (Inst. 6.3.14-17): “Assim, durante os banquetes e em conversas familiares descobrem-se muitas pessoas mordazes, já que progredimos através da prática cotidiana: a urbanidade oratória é rara e não deriva de uma técnica específica, mas deste hábito rotineiro. [...] Com efeito, quando se fala de urbanidade, vejo indicar-se com esta palavra precisamente um certo gosto citadino [gustum urbis] que é manifestado no discurso através dos vocábulos, da pronúncia e de seu uso particular, bem como uma erudição tácita adquirida das conversas entre pessoas cultas; em suma, tudo o que é contrário à rusticidade."

${ }^{163}$ Marco Pórcio Catão, o Velho, cônsul em 195, já referido no parágrafo 260.

${ }^{164}$ Novamente, Quintiliano muda os personagens, mantendo o conteúdo principal da anedota (Inst. 6.3.110): "aqueles que pertencem ao mesmo gênero em que se encontram os risíveis e que, contudo, não causam o riso, como o que foi dito a respeito de Asínio Polião, igualmente hábil no discurso sério e nas brincadeiras [iocis]: 'É um homem para todas as horas'." Algo semelhante em português poderia ser dito através da expressão coloquial "É pau para toda obra". Suetônio relata a mesma frase a propósito de Pompônio Flaco e Lúcio Pisão, amigos do imperador Tibério (Tib. 42: iucundissimos et omnium horarum amicos). 
nenhuma ocasião da vida em que não convenha cultivar a graça e o refinamento. 272. Mas torno ao restante. Muito próximo dessa ironia é quando se utiliza uma palavra honrosa para denominar algo incorreto, como, por exemplo, quando Africano, ${ }^{165}$ como censor, expulsou de seu clã o centurião que não participara da batalha de Paulo, ${ }^{166}$ embora afirmasse que permanecera no acampamento para defendê-lo e perguntasse o motivo da repreensão. $\mathrm{O}$ Africano respondeu: "Não gosto de pessoas cuidadosas demais". 273. Além disso, o gracejo é agudo quando se tira da fala de outro um sentido diferente do que ele pretendia, como, por exemplo, Máximo ${ }^{167}$ fez com Lívio Salinátor, ${ }^{168}$ quando, apesar da queda de Tarento, ${ }^{169}$ Lívio conseguira reter a sua cidadela e, a partir dela, realizara muitos combates célebres. Quando, anos depois, Máximo reconquistou aquela cidade e Salinátor pediu que se lembrasse de que Tarento fora reconquistada graças a ele, Máximo respondeu: "Como não me lembraria? Eu nunca a teria reconquistado se você não a tivesse perdido.” 274. Há também aqueles gracejos bastante absurdos, ${ }^{170}$ mas por isso mesmo muitas vezes engraçados, muito apropriados não apenas aos mimos, mas, de certa forma, também a nós:

"Um tolo:

Depois que começou a ganhar dinheiro, morreu."

"O que essa mulher é sua? - Esposa. - Por Júpiter, é a sua cara!"

"No tempo em que ia aos banhos, nunca morreu."

Esse gênero é bastante trivial e, como disse, próprio dos mimos. Porém, por vezes tem algum lugar também entre nós, que alguém, mesmo não sendo tolo, fale alguma tolice com humor - como Mância ${ }^{171}$ fez com você, Antônio, quando ouviu que você estava sendo acusado de

\footnotetext{
${ }^{165}$ A referência é ao mesmo Públio Cornélio Cipião Emiliano Africano, o Jovem.

166 Trata-se da batalha de Pidna, em 168, contra o rei da Macedônia, Perseu. Lúcio Emílio Paulo Macedônico, cônsul em 182 e 168, pôs fim à terceira guerra macedônica e ao que restava do império de Alexandre, o Grande.

${ }^{167}$ Quinto Fábio Máximo Cunctator, cônsul em 233, 228, 215, 214 e 209 e ditador em 221, cujo cognomen, "Procrastinador" (do verbo cunctare/ $i$, atrasar, hesitar, agir com lentidão), estaria relacionado à estratégia militar de evitar confronto direto com Aníbal durante a segunda guerra púnica (Liv. 28.40 e 30.26; Inst. 8.2.11).

${ }^{168}$ Marco Lívio Salinátor, cônsul em 219 e 207, criou um imposto sobre o sal na época do segundo consulado, o que explica o cognomen Salinator.

169 Alude-se à queda e à reconquista da cidade costeira de Tarento (respectivamente em 212 e 209), durante a segunda guerra púnica. A mesma anedota é contada por Cícero em Sen. 11, e, tanto aqui como na obra posterior, o Arpinate parece ter confundido Marco Lívio Salinátor com Marco Lívio Macato, comandante da guarnição de Tarento em 214, segundo Tito Lívio (27.34).

${ }^{170}$ A classificação do tipo de gracejo (subabsurda) é idêntica em Cícero e Quintiliano, mas os exemplos são diversos (Inst. 6.3.99): "Um tanto absurdas são aquelas estratégias que consistem em simular ignorância (as quais, se não forem fingidas, são realmente tolas), como o que disse um homem à gente que se interrogava por que ele comprara um candelabro pequeno: 'será para o almoço'.'

${ }^{171}$ Hélvio Mância (cf. 266).
} 
corrupção eleitoral, quando censor. Ele disse: "enfim poderá cuidar de sua própria vida!" 275. As pessoas riem muito disso e, sem dúvida, de tudo que os sagazes dizem ironicamente, de maneira bastante absurda e espirituosa. A esse gênero pertence também a aparência de desentendimento daquilo que se entende, como fez Pontídio, por exemplo: "Como você julga aquele que é flagrado em adultério?" - "Lento!"172 Como eu, que, num recrutamento, respondi a Metelo, que não aceitou minha desculpa da vista e disse: 276. "Então você não enxerga nada?" Respondi: "Do Portão Esquilino, enxergo a sua casa de campo"173. Como o gracejo de Nasica, ${ }^{174}$ que, quando foi à casa do poeta Ênio, uma serva respondeu a ele, que perguntava por Énio da entrada, que este não estava em casa; Nasica percebeu que ela dissera isso por ordem de seu senhor, e que ele estava lá dentro. Poucos dias depois, quando Énio foi à casa de Nasica e perguntou por ele à porta, Nasica grita que não está em casa. Então Ênio diz: “O quê? E eu não conheço a sua voz?” Nesse momento Nasica replicou: "Você é um impudente! Eu, quando o procurei, acreditei quando sua serva disse que você não estava em casa, e você não acredita em mim?!"

277. Também é fino aquele gracejo em que se devolve na mesma moeda a zombaria de alguém, como, por exemplo, quando Quinto Opímio, ${ }^{175}$ um consular, que, quando jovem, tivera péssima reputação, disse a Décio, um homem alegre que parecia bastante efeminado, embora não o fosse: "E você, minha Decinha? Quando virá a minha casa com sua roca e sua lã?” Ele respondeu: "Eu não me atrevo, por Pólux! Minha mãe me proibiu de me aproximar de mulheres de má reputação.”176

278. Também são espirituosos os gracejos que apresentam uma suspeita velada de risível. A esse gênero pertence aquele do siciliano: quando um amigo se queixava a ele, dizendo que sua esposa se enforcara numa figueira, ele respondeu: "Você poderia me passar umas mudas dessa árvore, para eu plantar?"177 A esse mesmo gênero pertence a observação que Cátulo fez a um mau orador. Como ele julgava que provocara misericórdia em seu epílogo, perguntou a Cátulo, depois de se sentar, se lhe parecia que seu discurso havia provocado

\footnotetext{
${ }^{172}$ A anedota é relatada por Quintiliano, em Inst. 6.3.87, com apagamento do nome "Pontídio".

${ }^{173}$ O Portão Esquilino, próximo ao Monte Esquilino, uma das célebres sete colinas de Roma, marca o local onde pobres e escravos eram enterrados (puticuli, cf. Var. L. L. 5.25). A frase de César parece ter sido uma crítica ao status social de Metelo.

${ }^{174}$ Públio Cornélio Cipião Nasica Optimus, cônsul em 191 ou seu filho Públio Cornélio Cipião Nasica Serapião Corculum, cônsul em 162.

${ }^{175}$ Quinto Opímio, pretor em 157 e cônsul em 154 (cf. Lucil. 11.450).

${ }^{176}$ Sobre "devolver na mesma moeda", Quintiliano invoca o exemplo de Cátulo e Filipe (Inst. 6.3.81): "Algo parecido é não negar o que se apresenta, mesmo quando isso for obviamente falso, e daí encontrar argumento para responder bem, como fez Cátulo a Filipe, que lhe interrogava 'por que ladra?': 'estou vendo um ladrão', disse."

${ }^{177}$ Quintiliano também aborda a "suspeita velada de risível" (suspicio ridiculi abscondita) em Inst. 6.3.88: "A esse caso assemelha-se o que é dito por insinuação (suspicionem): por exemplo, aquilo que, segundo Cícero, foi dito para um homem que lamentava o fato de a esposa ter se enforcado em uma figueira: 'Por favor, me dê uma muda dessa árvore para plantar'. Assim, o que não é dito fica subentendido."
} 
misericórdia. Ele respondeu: "E muita. Não creio que haja um só homem tão duro que não tenha considerado seu discurso digno de misericórdia." 279. Decididamente, também me fazem rir os gracejos irritados ${ }^{178} \mathrm{e}$ um tanto mal-humorados - não quando são ditos por alguém mal-humorado, pois então não se ri da piada, mas da natureza da pessoa. Nesse gênero, segundo me parece, é espirituosíssimo aquele gracejo que se lê em Nóvio:

- Por que choras, pai?

- Te admira que eu não esteja cantando? Fui condenado.

Como que em contraposição a esse gênero aparece o do risível paciente e calmo, como, por exemplo, quando Catão foi atingido por alguém que carregava um baú. Quando este disse, depois, “cuidado!", ele perguntou se estava carregando outra coisa além de um baú. 280. Existe também a repreensão espirituosa da estupidez, ${ }^{179}$ como no caso daquele siciliano, a quem o pretor Cipião ${ }^{180}$ oferecia seu hóspede, um homem nobre, mas absolutamente estúpido, como patrono de sua causa. Ele disse: "Por favor, senhor pretor, passe esse patrono a meu adversário; depois, não precisa me passar mais ninguém." Também provocam o riso os gracejos que oferecem uma explicação bastante distante da realidade, mas aguda e harmoniosa, por meio de uma conjectura, como quando Escauro acusou Rutílio ${ }^{181}$ de corrupção eleitoral, depois que o próprio Escauro fora eleito cônsul e Rutílio fora derrotado. Em seus registros, mostrou as letras E. F. P. R., dizendo que significavam "expensas feitas por Públio Rutilio". Já Rutílio disse que significavam "expensas feitas, posteriormente registradas". Gaio Cânio, cavaleiro romano, quando defendia Rufo, brada que aquelas letras não querem dizer nenhuma das duas coisas. Escauro pergunta: "Mas o que querem dizer, então?” Ele responde: Emílio ${ }^{182}$ fez, paga Rutílio".

281. Também se ri das incongruências: "o que lhe falta além de patrimônio e virtude?"183 Também é fina a repreensão amigável de alguém, como se ele estivesse cometendo um

${ }^{178}$ Inst. 6.3.99: "Similares às soluções absurdas são as ásperas [acria], que são pronunciadas aparentemente sem intenção, como no caso do escravo de Dolabela, que, sendo interrogado sobre um leilão que seu senhor teria proposto, respondeu: 'vendeu até a casa'." Dolabela, genro de Cícero, estaria coberto de dívidas. Assim, pode ter aceitado o suborno de Antônio, que recrutava aliados para o seu partido. A resposta dada pelo escravo de Dolabela parece até muito discreta, pois se a casa já tinha sido vendida, absolutamente mais nada de seu poderia ir a leilão.

${ }^{179}$ Inst. 6.3.71: "Censurar tolices é facílimo, até porque são ridículas por si só. Se, entretanto, acrescentamos o nosso toque pessoal, eis a urbanidade. Tolamente, Tício Máximo perguntou a Campácio, que saía do teatro, se ele assistia ao espetáculo. Campácio tornou a pergunta dele ainda mais tola, respondendo: 'não, eu estava jogando péla no palco'."

${ }^{180}$ Lúcio Cornélio Cipião Asiático, pretor na Sicília em 193 e cônsul em 190 (cf. Liv. 39.44).

${ }^{181}$ Públio Rutílio Rufo, pretor em 111 e cônsul em 105. Sobre as atividades oratórias de Rufo e Escauro, cf. Cícero, Brut. 110.

${ }^{182}$ Marco Emílio Escauro, já referido anteriormente, nos parágrafos 257 e 265.

${ }^{183}$ Inst. 6.3.84: “O chiste inesperado normalmente é enunciado tanto por quem ataca (tal é o que relata Cícero: 'O que falta a esse homem além de virtude moral e bens materiais?' Ou aquele de Afro: 
erro. Foi o que aconteceu quando Grânio censurou Álbio porque, apesar de Albúcio ${ }^{184}$ aparentemente ter provado uma questão fazendo uso dos registros de Álbio, este mostrava grande contentamento pela absolvição de Cévola, sem perceber que o veredito contradizia seus registros. 282. Semelhante a esta é também a advertência amigável quando se dá um conselho, como, por exemplo, quando Grânio estava tentando convencer um mau patrono, que ficara rouco enquanto discursava, a beber vinho gelado com mel assim que voltasse para casa. Ele disse: "Eu perderei a voz, se fizer isso". "É melhor do que perder o cliente", respondeu Grânio. 283. O gracejo é fino também quando se fala algo adequado a cada um, como, por exemplo, quando Escauro era objeto de alguma inveja por ter entrado na posse dos bens de Pompeu Frigião, homem rico, sem testamento, e prestou assistência a Béstia ${ }^{185}$ como advogado de defesa. Quando passava um cortejo fúnebre, Gaio Mêmio, o acusador, disse: "Olhe só, Escauro, estão levando um morto, veja se pode entrar na posse de seus bens." 284. Porém, de todos esses tipos, nenhum é mais engraçado do que o que contraria as expectativas. Há inúmeros exemplos disso, como o do famoso Ápio, o Velho, que disse no Senado, quando se discutia sobre as terras públicas e a lei tória, ${ }^{186}$ e quando Luculo era processado pelos que alegavam que o seu gado estava pastando nas terras públicas: "Aquele não é o gado de Luculo, estão enganados - ele parecia estar defendendo Luculo -; creio que não é de ninguém, pasta onde bem entende". 285. Gosto também do gracejo do famoso Cipião, ${ }^{187}$ que deu cabo de Tibério Graco. Quando Marco Flaco, ${ }^{188}$ depois de lhe lançar muitas injúrias, lhe propôs Públio Múcio ${ }^{189}$ como juiz, Cipião disse: "Recuso-o, pois ele é injusto." Como houve um rumor, continuou: "Ora, senhores senadores, não o recuso por ser injusto comigo, mas com todos." Mas nada mais espirituoso do que o gracejo deste nosso Crasso. Quando Silo, em seu testemunho, atacou Pisão por ter relatado o que ouvira dizer contra ele, Crasso disse: "Pode ser, Silo, que a fonte de onde você alega ter ouvido isso estivesse irada ao dizê-lo." Silo anuiu. "Pode ser também que você não tenha entendido bem." Também a isso anuiu inteiramente com a cabeça, como se a oferecesse a Crasso. Ele continuou: "Pode ser também que você simplesmente nunca tenha ouvido o que alega ter

'Um homem que, em se tratando de advogar, veste-se muito bem') como por quem rebate. Assim fez Cícero quando ouviu o boato da morte de Vatínio e, tendo encontrado um liberto deste, perguntou se estava tudo bem e obteve uma resposta positiva, ao que replicou: 'Está morto!'.”

${ }^{184}$ Tito Albúcio (pretor em 105) teria movido um processo por extorsão contra Quinto Múcio Cévola em 119 (cf. Lucil. 2.88).

${ }^{185}$ Lúcio Calpúrnio Béstia, tribuno da plebe em 121 e cônsul em 111.

${ }^{186} \mathrm{O}$ tribuno Espúrio Tório propôs em 111 uma lei que limitava os efeitos da privatização do ager publicus, reservando a propriedade legal de cada porção de terra a seus ocupantes (cf. App. BC 1.27). ${ }^{187}$ Públio Cornélio Cipião Nasica Serapião, cônsul em 138 e 133, filho de Públio Cornélio Cipião Nasica Serapião Corculum. Nas Tusculanas (4.23.51), Cícero também relata que este Cipião teria "se encarregado" de Tibério Graco.

${ }^{188}$ Marco Fúlvio Flaco, cônsul em 125, partidário dos Gracos (mencionado por Cícero em Catil. 1.4 e Phil. 8.14: M. Fuluius consularis).

${ }^{189}$ Públio Múcio Cévola, cônsul em 133 e pontifex maximus no ano de 131, cuja conduta era marcada pela probidade e moderação. 
ouvido." Isso aconteceu tão inesperadamente, que a testemunha foi esmagada pelo riso de todos. Nóvio está cheio desse tipo de gracejo - é conhecida a brincadeira: "Ainda que sejas sábio, se sentires frio, tremerás" ${ }^{190}$-, entre inúmeras outras. 286. Muitas vezes, também, podese conceder graciosamente ao adversário exatamente aquilo que ele tira de você, como Gaio Lélio, ${ }^{191}$ por exemplo, quando alguém oriundo de má estirpe lhe disse que era indigno de seus antepassados. Ele respondeu: “Ora, mas você certamente é digno dos seus.” Muitas vezes, ainda, falam-se coisas jocosas de maneira sentenciosa, como, por exemplo, Marco Cíncio, ${ }^{192}$ no dia em que propôs uma lei concernente aos presentes e às dádivas. Quando Gaio Cento ${ }^{193}$ se aproximou e perguntou, em tom bastante ultrajante: "O que está propondo, Cincinho?" Ele respondeu: "Que você pague, Gaio, se quiser usar." 287. Muitas vezes é também espirituoso desejar o que é impossível, como fez Marco Lépido, ${ }^{194}$ por exemplo, quando se deitou na grama enquanto os demais se exercitavam no Campo de Marte. Ele disse: "Gostaria que isto fosse trabalhar." Também é espirituoso dar com frieza a resposta indesejada àqueles que perguntam e fazem uma espécie de interrogatório, como, por exemplo, o censor Lépido, ${ }^{195}$ quando expulsou Marco Antístio Pirgense da ordem equestre, e seus amigos esbravejaram, perguntando-lhe o que Antístio responderia a seu pai quando indagasse o motivo de sua expulsão, uma vez que era um colono excelente, extremamente parcimonioso, modesto, frugal. Ele respondeu: "Que eu não acredito em nada disso."196 288. Os gregos catalogam mais alguns tipos: as execrações, as admirações, as ameaças. Porém, creio que já os dividi em gêneros demais. De fato, aqueles que se baseiam na conformação e no sentido da palavra quase sempre são fixos e delimitados. Na maior parte dos casos, como disse anteriormente, costumam ser recebidos antes com elogios que com risos. 289. Já aqueles que se baseiam

${ }^{190}$ Anedota semelhante é relatada por Quintiliano em Inst. 6.3.60: “Certos casos quase não são símiles, daí tirou Vatínio o que disse, quando, na condição de réu, acusado por Calvo, enxugava o rosto com um lenço branco e ouvia o acusador incitar o repúdio sobre esse mesmo fato: 'embora eu seja o réu, o pão que como ainda é branco'.” Licínio Calvo, orador e poeta neotérico (amigo de Catulo), acusou três vezes Públio Vatínio (seguidor de César) de fraude eleitoral em 58, em 55 e talvez em 54. Quanto ao dito de Vatínio, talvez haja uma referência ao fato de o panis candidus (pão branco) custar mais do que o panis cibarius (pão preto do qual normalmente pobres e escravos se alimentavam).

${ }^{191}$ Gaio Lélio, o Jovem, cônsul em 140, considerado um orador proeminente já em seu tempo. Foi amigo de Cipião Emiliano, ambos personagens do diálogo ciceroniano De amicitia.

${ }^{192}$ Marco Cíncio Alimento, tribuno da plebe em 204.

${ }^{193}$ Gaio Cláudio Cento, cônsul em 240 e ditador em 213, ou seu filho homônimo, emissário do cônsul Públio Máximo em 200.

${ }^{194}$ Pela proximidade entre um exemplo e outro, pode-se aventar que este Marco Lépido seja o censor sobre o qual se lê na sequência, embora seja impossível afirmá-lo com certeza.

${ }^{195}$ Marco Emílio Lépido, cônsul em 187 e 175 e censor em 179.

${ }^{196}$ Quintiliano narra episódio semelhante em Inst. 6.3.64, atribuindo-o não a Lépido, mas a Augusto: "Os tipos de chistes que derivam de opostos são mais de um. Com efeito, usando esse método, Augusto, que deveria demitir com ignomínia um oficial que repetidamente intercalava às súplicas a seguinte frase: 'o que vou dizer a meu pai?', respondeu: 'diga-lhe que eu não lhe agradei’.’ 
na matéria e no próprio pensamento apresentam inumeráveis espécies, mas poucos gêneros. De fato, provocamos o riso frustrando as expectativas, zombando do caráter dos outros, acenando para o nosso de maneira risível, fazendo uma comparação com algo mais torpe, pela ironia, dizendo coisas extremamente absurdas e repreendendo as tolices. Assim, aquele que quiser discursar de maneira jocosa deve estar imbuído como que de uma natureza e de um caráter aptos a esses gêneros, de modo que a expressão facial também seja adequada a qualquer gênero de risível. Quanto mais sério e sisudo ele for, como em seu caso, Crasso, mais saboroso será aquilo que disser. ${ }^{197}$

290. Mas agora você, Antônio, que disse que descansaria de bom grado nesta hospedaria de minha fala, como se se hospedasse em Pontino ${ }^{198}$ - lugar nada ameno ou salubre - creio que deve considerar seu descanso suficiente e seguir viagem.

- Na verdade, respondeu Antônio, fui recebido por você com bom humor, tornando-me não apenas mais instruído por seu intermédio, mas também mais ousado para fazer brincadeiras. De fato, não receio que agora alguém me considere muito banal nesse domínio, uma vez que você me apresentou como autoridades os Fabrícios, Africanos, Máximos, Catões, Lépidos.

\section{Abreviações}

LIMC -Lexicon Iconographicum Mythologiae Classicae, Zürich München, 1981.

LPN - Leeman, A. D.; Pinkster, H.; Nelson, H. L. W. (com.). M. Tullius Cicero De oratore libri III: Kommentar. Heidelberg: Carl Winter Universitätsverlag, 1985. v. 2.

LPR - Leeman, A. D.; Pinkster, H.; Rabie, E. (com.). M. Tullius Cicero De oratore libri III: Kommentar. 3. Heidelberg: Carl Winter Universitätsverlag, 1989. v. 3.

\section{REFERÊNCIAS}

ALBERTI, V. O riso e o risivel na história do pensamento. 2 ed. Rio de Janeiro: Zahar, 2002.

ARISTÓTELES. Poética. Tradução de Ana Maria Valente. 3 ed. Lisboa: Calouste Gulbenkian, 2008.

\footnotetext{
${ }^{197}$ Quintiliano faz recomendação semelhante em Inst. 6.3.26: “O mesmo também seja dito sobre uma aparência ou gesto ridículo: há nisso realmente certa graça, mas o efeito é maior quando a intenção de suscitar o riso não é evidente, pois nada é mais insosso do que as frases que se dizem engraçadas [salsa]. Ainda que a seriedade possa acrescentar muita graça a quem profere uma frase, e esta se torne ridícula justamente porque esse que fala não ri, às vezes a aparência, a fisionomia e os gestos não são, todavia, menos urbanos [non inurbanus], desde que observados os limites.”

${ }^{198}$ Região de pântanos nas proximidades de Roma (cf. Liv. 6.5).
} 
[CÍCERO]. Retórica a Herênio. Tradução de Ana Paula Celestino Faria e Adriana Seabra. São Paulo: Hedra, 2005.

CONTE, G. B. Letteratura latina: manuale storico dalle origini alla fine dell'impero romano. Milano: Le Monnier, 2011.

CORBEILL, A. Controlling laughter:political bumor in the late Roman Republic. Princeton: Princeton University Press, 1996.

COURBAUD, E. Cicéron: De l'orateur. Livre premier. Texte établi et traduit par Edmond Courbaud. 7 ed. Paris: Belles Lettres, 1985.

DOMINIK, W.; HALL, J. (ed.). A Companion to Roman Rhetoric. Oxford: Blackwell, 2007.

FANTHAM, E. The Roman world of Cicero's De oratore. Oxford: Oxford University Press, 2004.

FORTENBAUCH, W. W. Theophrastean Studies. Stuttgart: Franz Steiner Verlag, 2003.

GRANAROLO, J. Catulle, ce vivant. Paris: Belles Lettres, 1982.

GRANT, M. A. The ancient rhetorical theories of the laughable: the Greek rhetoricians and Cicero. Madison: University of Wisconsin, 1924.

ISO, J. J. Cicerón: sobre el orador. Introducción, traducción y notas de José Javier Iso. Madrid: Gredos, 2002.

JANKO, R. Aristotle on comedy: towards a reconstruction of Poetics II. London: Duckworth, 1984.

KUMANIECKI, K. F. (ed.). M. Tulli Ciceronis scripta quae manserunt omnia. Leipzig: Teubner Verlagsgesellschaft, 1969. fasc. 3.

MAY, J. M.; WISSE, J. (trad.). Cicero. On the Ideal Orator. New York: Oxford University Press, 2001.

MINOIS, G. (org.). História do riso e do escárnio. São Paulo: Unesp, 2003.

MIOTTI, C. M. Ridentem dicere nerum: o humor retórico de Quintiliano e seu diálogo com Cícero, Catulo e Horácio. Tese (Doutorado em Linguística) - Instituto de Estudos da Linguagem, Universidade Estadual de Campinas, Campinas, 2010.

NÓBREGA, V. L. da. Compêndio de direto romano. Rio de Janeiro: Freitas Bastos, 1977. v. 1.

NORCIO, G. M. Tullio Cicerone: Opere retoriche. Torino: UTET, 1970. v. 1.

POSSENTI, S. Humor, lingua e discurso. São Paulo: Contexto, 2014.

SANTORO, F. Tratado Coisliniano. Letras Clássicas, ano 11, n. 7, p. 275-81, 2003.

SCATOLIN, A. A invenção no Do orador de Cícero: um estudo à luz de Ad Familiares I, 9, 23. Tese (Doutorado em Letras Clássicas) - Faculdade de Filosofia, Letras e Ciências Humanas, Universidade de São Paulo, São Paulo, 2009. 
SHACKLETON BAILEY, D. R. Onomasticon to Cicero's Treatises. Leipzig: Teubner, 1996.

SMITH, W. (ed.). Dictionary of Greek and Roman biography and mythology. Boston: Little, Brown, and Co., 1867. v. 3.

VAHLEN, J. Ennianae poesis reliquae. Leipzig: Teubner, 1928.

VILJAMAA, T. Quintilian's theory of wit. In: JÄKEL, S.; RISSANEN, V-M.; TIMONEN, A. (org.). Laughter down the centuries. Turku: Turun Yliopisto, 1994. v. 1. 